\title{
継続歯の根面に加わる咬合力および 咀噮力に関する研究
}

\author{
天野秀 雄 \\ Distribution of Biting and Masticatory Forces Applied \\ to the Root Surface of an Upper Central \\ Incisor with a Post Crown
}

Hideo Amano

\section{緒言}

継続莼やコアーを施したジャケットクラウンは天然蒾 の形態や色調を再現することが容易であり，またその排 列も比較的自由であるという特徴をもつている.だから， 前画部の無髄処固齔の補綴によく用いられている。しか し，臼歯部の代表的歯冠補緅物である鋳造冠に比べる

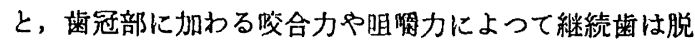
落したり，あるいはジャケットクラウンは破折したりす る欠点がある.

ところが,このような欠点は，少なくとも継続歯では その苗冠の長さおよび傾斜, 合釘の長さと形態, 歯冠部 に加わる咬合力または咀唃力の大きさと方向などに関係 があると考えられるので，咬合，咀吻時に継続噛の根面 に加わる力の大きさ、方向および分布様式などを左右す る諸要因を力学的に解明することは, 継続蔽を設計して 作製するためにも，また装着後の脱落を防ぐためにもき わめて重要な課題である.

従来, 補縀物および支台业に加わる力を力学的に解明 する方法としては, 光弾性実験法 ${ }^{1-38)}$, 応力塗料法 59-63) およびストレインゲージ法64-87)がよく用いられている.

しかし,この種の硎究には模型実験が多く, 生体で㨁 接测定した報告はきわめて少ない(表 1 ).

ところが，生体においては画根膜や額管などが存在し

Department of Prosthodontics, Osaka Dental University (Director: Prof. Tomio Komori)

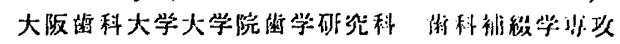

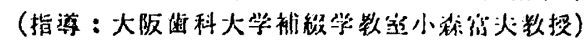
昭和45作 4 月 30 日桑付
ているから，咬合，勗覆時の補緅物に対する加王の状悲 も生体における钼察と模型についての垁験とでは当然毘 なる.したがつて，模型についてだけでなく生体につい ても観察する必要がある.

そこで，著者はストレインゲージを応用して，上顥中 切歯継続歯の根面の各部 (唇侧部, 舌側部, 近心側部括 よび遠心侧部の四部位）に加わる咬合力や组嗅力の大き さから，継続墦の根面に加わる力の方向および分布様式 を值接测定できる受圧㳖圆を考案し，この受仼装置を設 置した継続迷（これを契験用継続均と呵ふ）を生体およ び模型に適用して，いろいろの垁験条件において支台困 の根面に加わる力を测定しょうと考えた.

しかし，口腔内の支台歯に実験用継続歯をセメント装 着してしまうと箺験後にそれを撤去することが困難とな るので，セメント装着をしないで測定するほうが便利で ある．そこで，実験用継続虚をセメント装着をしないで 測定したときとセメント装着をした場合とでその実験成 績に差異があるかどうかを検討しておく必要があるの でまずこの点を確かめるために予嗝実験を行ない,つ いで本灵験に移つた。

そして，継続莯支台歯の根面に加わる嘫合力および咀

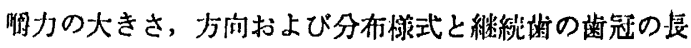
さや傾斜あるいは合釷の長さや形悲などとの関係を検討

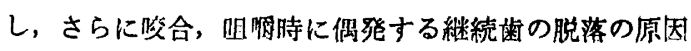
について考终したのでその絬果を報貨する.

\section{実験材料と実験方法}

1. 被検酙

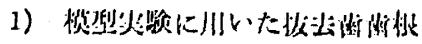


表 1

A. 光强性実题法

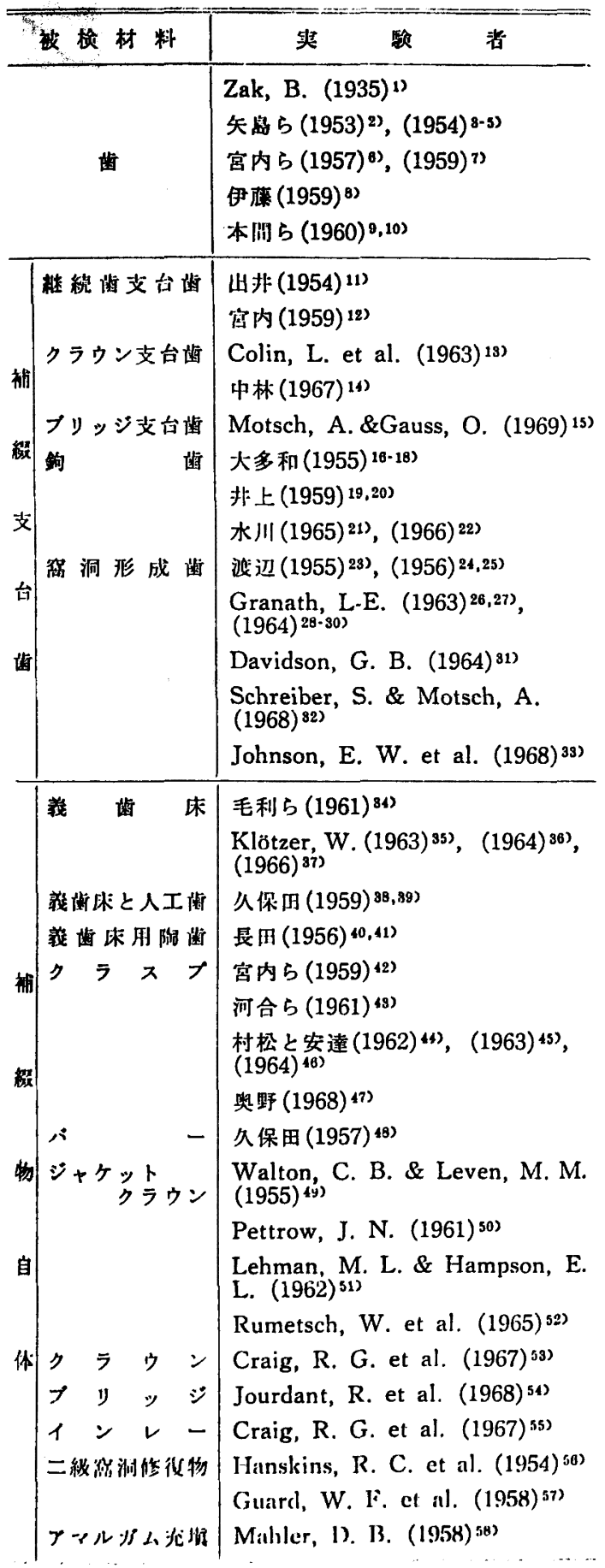

B. 応力堽料法

\begin{tabular}{|c|c|c|c|c|}
\hline \multicolumn{2}{|r|}{ 被椧 材 料 } & 夾 & 歌 & 渚 \\
\hline \multirow{5}{*}{$\begin{array}{l}\text { 被物 } \\
\text { 物 } \\
\text { 自 } \\
\text { 体 }\end{array}$} & \multirow{3}{*}{ 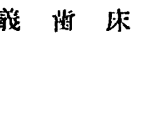 } & \multirow{3}{*}{\multicolumn{3}{|c|}{$\begin{array}{l}\text { 村松 } 5(1954)^{50)} \\
\text { Matthews, E. \& Wain, E. A. (1956) }{ }^{602} \\
\text { 杉田 (1967) }\end{array}$}} \\
\hline & & & & \\
\hline & & & & \\
\hline & クラスプ & \multicolumn{3}{|c|}{ 宝田 (1963) ${ }^{62)}$} \\
\hline & プリッジ & Craig, R. G. \& I & Peyto & A. $(1965)^{63)}$ \\
\hline
\end{tabular}

C. ストレイングージ法

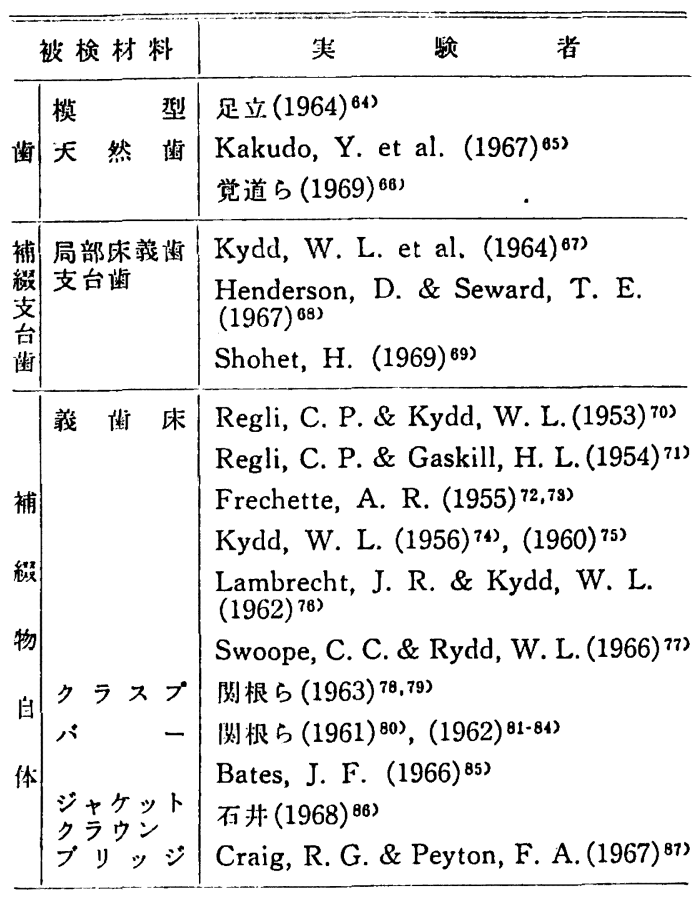

㴹根の絡曲していない比校的大きな健全上歌中切歯の 拔去歯药根を用いた。

2）模型実験に用いたレジン蒾根

上颚中切歯歯根の 2 倍大の歯根模型をアクリリックレ ジンで作製して被検得とした。

3）生体での実験に用いた被検潾

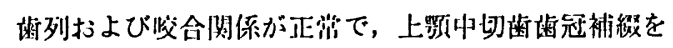
適応症とした有海影者 4 人（本学学生: 年路 20 歳から 30 歳の男子）の無蹎処㽡を完了した上䫑中切迷を被検歯と した.

\section{2. 被検菌の根面形成}

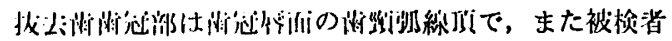

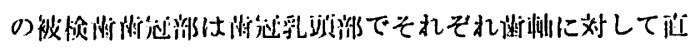

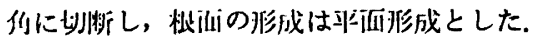




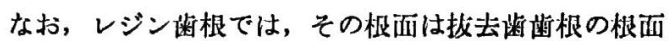
形成に準ずるようにあらかじめ作製して抽いた。

3. 合釘孔の形成

1）拔去菌歯根を用いた模型実験および生体での実験 では, 合釷孔の形成はつぎのようにして行なつた。 すな わち，合钉孔の鹿さおよび太さはそ机ぞれ歯根の長さの

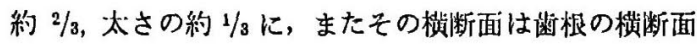
とほぼ相似形になるようにした，そして，加圧時に合猃 が回転するのを防ぐために，根面の合剑孔舌側部に小さ な箱形咹洞を形成した。

2）ただし，合釷の展さと料根蒾预部表面のひずみと

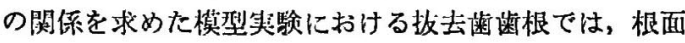
から根尖まで均一の太さ（直径 $2 \mathrm{~mm}$ ) の合釷孔を形成 した.

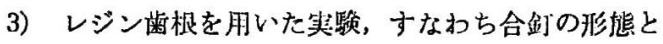
根面の各部に加わる力との関係について検澍した奉験で は，2 倍大の蔽根模型を作裴したので，これにともない 長径 $5 \mathrm{~mm}$ ，短径 $2 \mathrm{~mm}$ の偨円形合釷孔を根尖まで均一 の太さに形成した。

\section{4. 模型実験に用いた被検歯の固定}

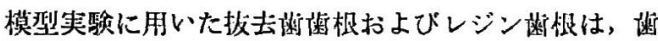
根歯頸部を $2 \mathrm{~mm} \sim 4 \mathrm{~mm}$ 路出させて，超硬石峦のブロ ックに植立固定した.

5. 継続苗支台菌の根面に加わる咬合・呾唧力測定装 置 (受庄装置)の作製と被検歯の根面への装着

1）受圧装置

受圧装置は，根面の唇侧部，舌侧部，近心侧部および 遠心侧部の四か所に設置した四っの片持はりの板（大き さ： $4 \mathrm{~mm}$ (縱) $\times 2 \mathrm{~mm}$ (横)，厚さ： $1 \mathrm{~mm}$, 片挂はり
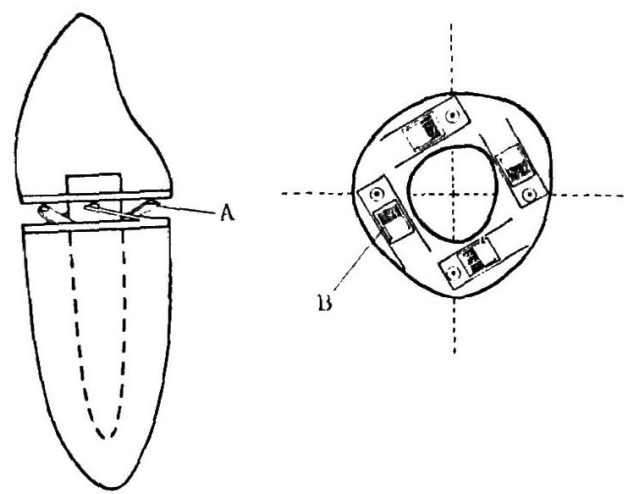

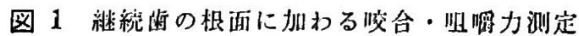
装说（受压装湴）

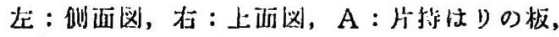
$\mathrm{B}$ : ストレインゲージ

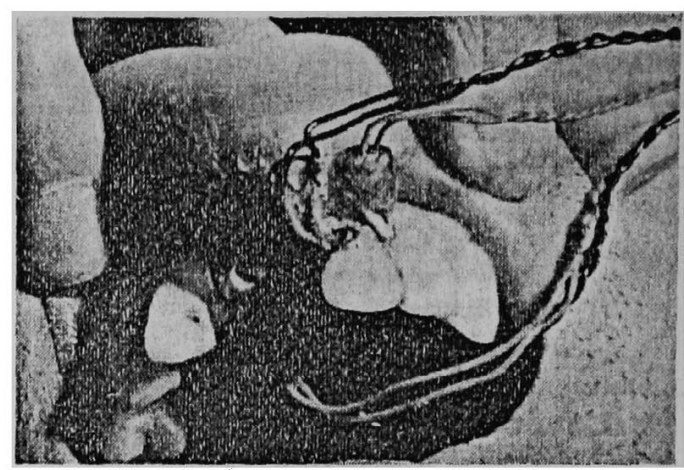

図2口腔内に根面に加わる咬合 咀螱力测定 装圈むよび実験用継続幽を装着した図

の板上には実験用継続歯の根面板との接点となる突起部 がある) とこの片持注りの板を支えるための一つの台座 とからなる(図1, 図 2).

2）受圧装㯰の作僬

片㩆はりの板と台侳とは一地としてパラジウム合金で 銶造し，熱処理して作製した。

片持はりの板にストレインゲージ（フォイルゲージ， 型名 : F 101, ゲージ長×蕾: $1 \mathrm{~mm} \times 1.5 \mathrm{~mm}$, 抵抗值 : $120.00 \Omega \pm 0.3 \%$ ，新興通信工業製) を，アロン・アルフ エ(シアノアクリレート系接著材，東亚合成化学工業 製) で貼付し，その上をポリエステル系接着材 (SP-3， 新興避信工業製) でうすく被覆して, 口腔内における湿 気に対して防湿，絶緣した。

3）受王装置の装着

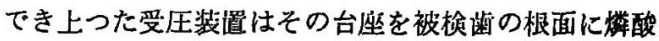
迎結セメントで装着した。

6. 実験用継続菌の作製

1）拔去潾料根についての模㤠笑験および坐体での实

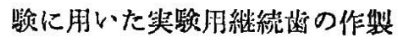

a）合剑㔚よび根面板をパラジウム合金で别個に鈛造 して作製する.

b）根面板と受代装㯰の四つの片持はりの板上の突起 部とが枃等に接蚛する状热で，合猃と根西板とをろう 䔆する。

c）合釷の歯冠部分を根面板の表面から $3 \mathrm{~mm}$ だけ残 して切断する. この合釷の歯冠部分を維持部としてレジ

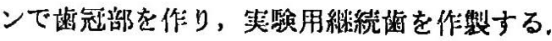

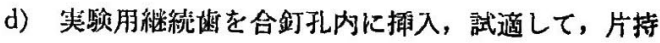
はりの板上の突起部にポリエステル系接着忉を少量盛つ て根面板と各突起部がな抢いっそう均等に接触するよう にする. 


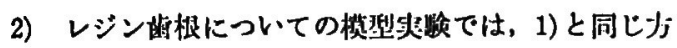
法で作つた実物の 2 倍大の实験用継続齿を合釘と合釬孔 との開陪を即時重合レジンで坦めてから，亚鉛蕉ユージ ノールペーストで装着した.

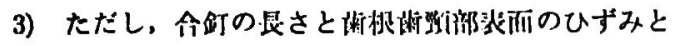
の関保を求的た拔去歯齿相における棪型然顷では，荷血

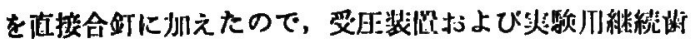

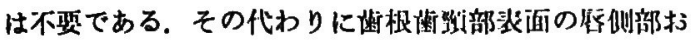
よび舌侧部に，䣫接ストレインゲージ（フォイルゲー ジ, 型名: F101, ゲージ長 $\times$ 幅 : $1 \mathrm{~mm} \times 1.5 \mathrm{~mm}$, 抵抗 值 : $120.00 \Omega \pm 0.3 \%$, 新與通信工業制) をアロン・アル ファで貼付した. また，合釘を根面から $5 \mathrm{~mm}$ 残して切 断した.

\section{7. 咬合力淜定器の作製}

Anderson, D. J. (1953) ${ }^{883}$ の装圈を応用して，厚さ $10 \mathrm{~mm}$ の签合力测定器（図 3）を作製した.

使用したストレインゲージはフォイルゲージ, 型名： F 102，ゲージ曼 $\times$ 幅 : $2 \mathrm{~mm} \times 2 \mathrm{~mm}$, 抵抗值 : $120.00 \Omega$ $\pm 0.3 \%$, 新興通信工業製である.

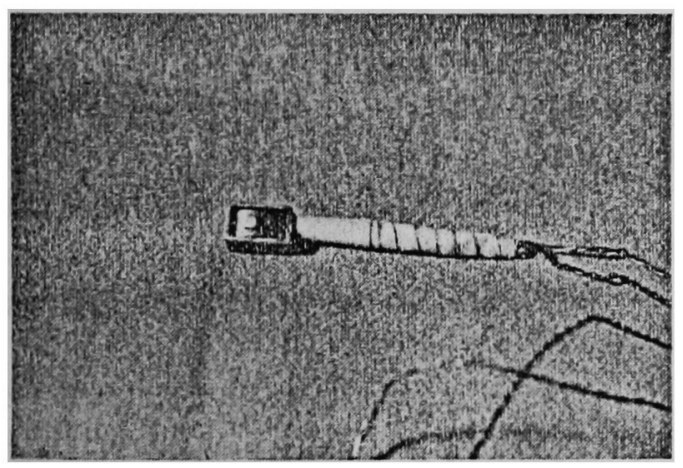

图 3 咬合力测定器

\section{8. 実倹用継精歯および合钉に加える荷重}

1）矢験用継続菌にはつぎのような方法で荷重を加え た. すなわち, 生体での実験では被検者に咬合力測定器 を咬合させ，また模型における実験では舌侧方向から断 䖩に対して $30^{\circ}$ の角度で歯冠切縁に $1 \mathrm{~kg}$ の荷重をばね 种りで加えた。

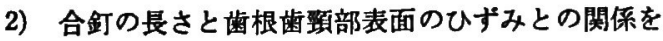
求めた実験では，直接合釘の先端に舌侧方向から歯軸に 対して直角に $1 \mathrm{~kg}$ および $2 \mathrm{~kg}$ の倚重をばね科りで加え た.

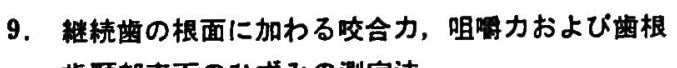
歯顒部表面のひずみの测定法

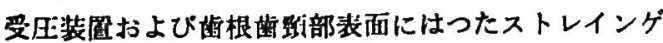

一ジからの各 outputはひずみ計用入力箱を介して、多 用途監視記録装滥（RM-150型，日本光雪工業製）で記 録した。

受圧装置の校正は，片持はりの板ばねに種々の大きさ

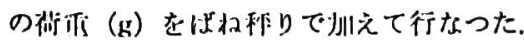

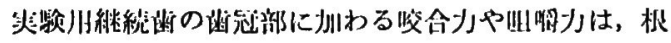

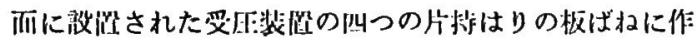
用与る。

そして，板面に玔わる力の大きさは片掉はりの板ば权 のひずみ量から判定することができるし，齿冠に加わる 力の方向は根䤄のどの部位の片持はりの板ばねが倒くか によって知ることができる，たとえば(図4)，矢弱用継

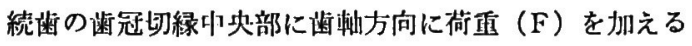
と, 根面の唇侧部, 舌侧部, 近心似部および蚞心侧部に
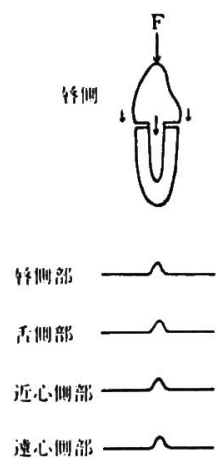
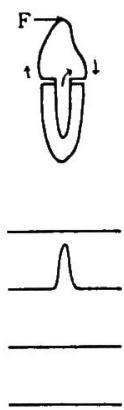
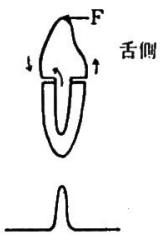

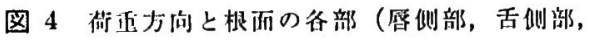

近心侧部，邆心侧部）に加わる力の記録波形

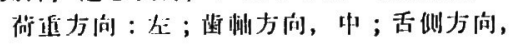
有; 娾似少向

設置された四つの片持はりの板ば权全部が作用し，唇侧 方向から舌側方向化荷重を加えるときには根面舌倒部の 片持はりの板ばねだけで柳く，そして，舌侧方向から唇 侧方向に荷重を加える場合には，根面唇例部の片持はり の板ばねだけが傎いて根面の唇侧部に力が作用したこと がわかる.

\section{実験成績}

\section{A. 予備実験}

头験用継続蔽のセメント装着前, および装着後におけ る荷重部位と根面の各部に加わる力の大きさ，および分 布様式とを比較する目的で，抜去歯实根を用いた模型に ついて実験し，つぎのような結果を得た（図 5 ，図 6 お よび表 2)。すなわち,

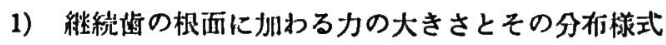




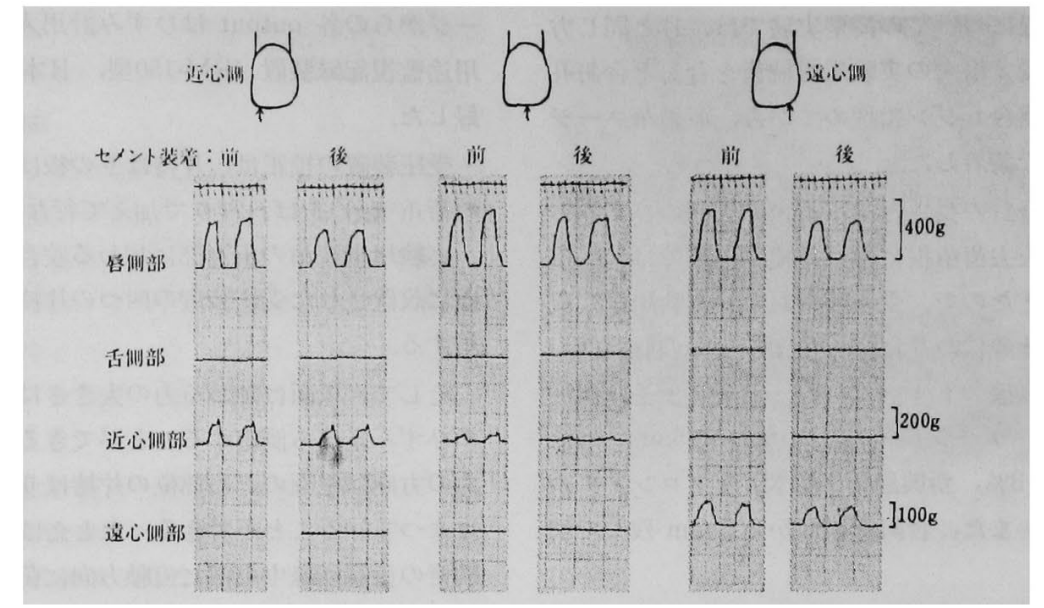

図 5 セメント装着前㧍よび装着後におうりる荷雷部位と根面の各部に加 わる力の記録波形

候重部位：左；切縁近心部，中；切縁中央部，右；切縁遠心部

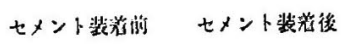

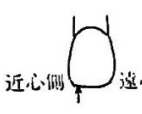
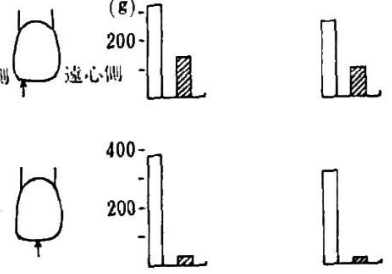

$400-$

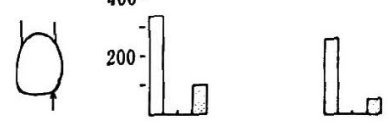

図 6 セメント装着前抢よび装請後に抢ける根 面の各部に加わる力の大きさの比枚 口: 根西唇侧部に加わる力, 路 : 根西近

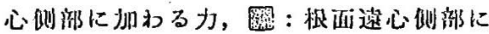
加わる力

莎重部位：上；切縁近心部，小；切緑中 火部，右 ; 切縁悳心部

とは，荷重を加える蒛冠切縁の部位が違うと異なる。

2）しかし，根面に加わる力の分板㥞式は，セメント
装着前と装着後とでは美翼は認められない，すなわち， セメント装着前でも装着後でも，

a）切縁近心部に荷重を与えたときには，根面唇側部 と根面近心倒部とに力が加わる.

b）切縁中央部に荷重を加えた場合は，大部分の力は 根面唇侧部だけに作用し，ごく一部分の力は根面近心側 部にも侀いている。

c）切縁遠心部に荷重を加えると，根面唇側部と根面 遠心側部とに力が作用する.

d）根面唇側部に加力る力は, 切縁中央部に荷重を加 えたときがもつとも大きい.

3）ところが，セメント装着してしまうと，切縁のど の部位に荷重を加えても, 根面の各部に加わる力の大き さは小さくなる.

4）しかし，セメント装着後における根面の各部に加 わる力の大きさの淢少率は，根而のどの部位においても ほとんど一定である.

5）なお，切縁のどの部位に荷重を加えても，またセ メント装着前でも装着後でも，根面舌側部には力は作用 していない.

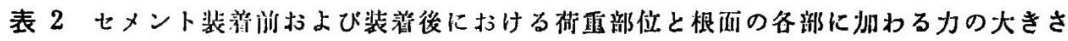

\begin{tabular}{|c|c|c|c|c|c|c|c|c|c|c|}
\hline \multirow{2}{*}{\multicolumn{3}{|c|}{ 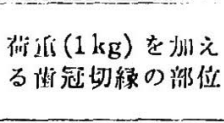 }} & \multicolumn{2}{|c|}{ 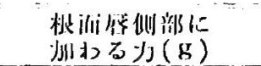 } & \multicolumn{2}{|c|}{ 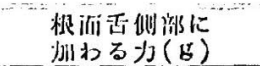 } & \multicolumn{2}{|c|}{$\begin{array}{l}\text { 恨面近心侧激に } \\
\text { 的わるめ }\end{array}$} & \multicolumn{2}{|c|}{ 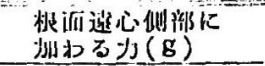 } \\
\hline & & & $\begin{array}{l}\text { セxント } \\
\text { 装溜施 }\end{array}$ & $\begin{array}{l}\text { セメント } \\
\text { 悲溜後 }\end{array}$ & $\begin{array}{l}\text { セxント } \\
\text { 芘着颜 }\end{array}$ & $\begin{array}{l}\text { セxント } \\
\text { 装湴後 }\end{array}$ & $\begin{array}{l}\text { せメント } \\
\text { 装彗前 }\end{array}$ & $\begin{array}{l}\text { セxント } \\
\text { 裴潧後 }\end{array}$ & $\begin{array}{l}\text { セメント } \\
\text { 装曾能 }\end{array}$ & 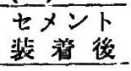 \\
\hline 近 & 心 & 蔀 & 320 & 260 & 0 & 0 & 140 & 100 & 0 & 0 \\
\hline 니 & 火 & 部 & 380 & 320 & 0 & 0 & 30 & 20 & 0 & 0 \\
\hline 邀 & 心 & 㴋 & 340 & 260 & 0 & 0 & 0 & 0 & 100 & 50 \\
\hline
\end{tabular}




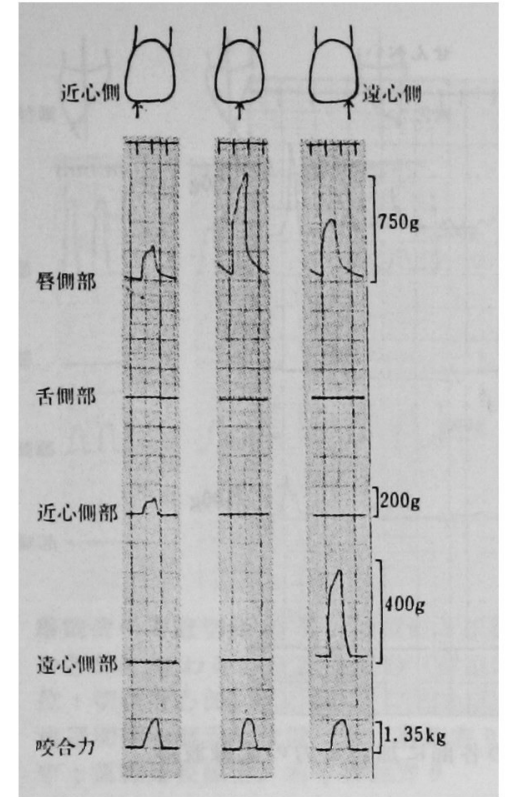

图 7 览合部位と根面の各部に加わる力の 部録波形

咬合郁位：左；切縁近心激，小；切 緑中火部，右; 切緑括心激

表 3 咬合部位と根面の各部に加わる力の大きさ

\begin{tabular}{|c|c|c|c|c|}
\hline $\begin{array}{l}\text { 咬合力 } 1350 \mathrm{~g} \\
\text { だの咬合部位 }\end{array}$ & $\mid \begin{array}{l}\text { 根面唇侧 } \\
\text { 部に加わ } \\
\text { る力 ( } \mathrm{g})\end{array}$ & 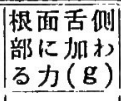 & $\begin{array}{l}\text { 根面近心侧 } \\
\text { 部に加わる } \\
\text { 力 ( } \mathrm{g})\end{array}$ & $\left\{\begin{array}{l}\text { 根酒遗心倒 } \\
\text { 部に加わる } \\
\text { 力 }(\mathrm{g})\end{array}\right.$ \\
\hline 近 心 部 & 200 & 0 & 40 & 0 \\
\hline 中 央 部 & 770 & 0 & 0 & 0 \\
\hline 遠 心 部 & 400 & 0 & 0 & 350 \\
\hline
\end{tabular}

以上の予備実験の結果から明らかなように，継続齔の 根面に加わる力の分布様式には，セメント装着前と装着 後とで差界がないので，以後の生体および抜去画歯根を 用いた模型実験はセメント装着をしないで行なつた.

B. 生体での実験

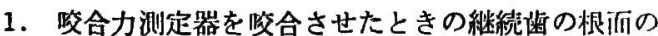
各部に加わる力

各被検者に継続歯の歯冠切縁の近心部，中央部および 違心部で同じ大きさの咬合力を用いて，また咬合力の大 きさを変えて咬合力测定器をかませた，そして，継続蕲 の根面の各部に加わる力の大きさおよびその分布様式を 湘定し，つぎのような成績を得た，各成績についてその 1 例を図 7, 図 8 , 表 3 , 表 4 に示す.

1）同じ大きさの咬合力で㗳合させたときの継続歯の 根面の各部に加わる力

a) 切縁近心部で咬合させるときには，根面唇侧部お

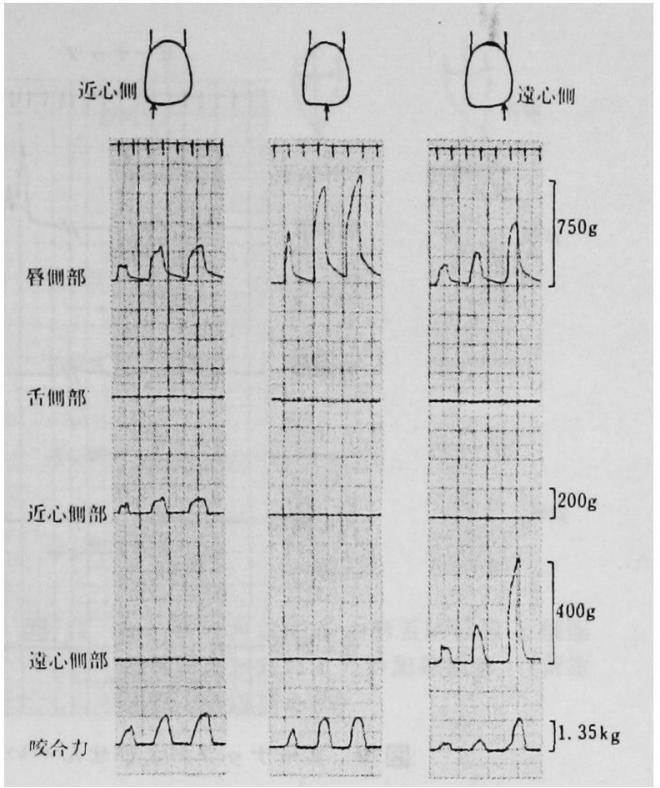

图 8 咬合力の大きさと根面の各部に加わる力 の記錄波形

表 4 咬合力の大きさと根沄の各部に加わる カの大きさ

\begin{tabular}{|c|c|c|c|c|c|}
\hline 咬合部位 & $\begin{array}{c}\text { 咬合力 } \\
(\mathrm{g})\end{array}$ & \begin{tabular}{|l|} 
根面唇例 \\
部に加わ \\
る力 $(\mathrm{g})$
\end{tabular} & $\begin{array}{l}\text { 根泊舌侧 } \\
\text { 部に加わ } \\
\text { る力 }(\mathrm{g})\end{array}$ & 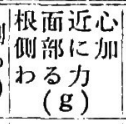 & $\begin{array}{c}\text { 根面遠心 } \\
\text { 侧部に扣 } \\
\text { わる力 } \\
(\mathrm{g})\end{array}$ \\
\hline \multirow{3}{*}{ 近心部 } & 900 & 30 & 0 & 20 & 0 \\
\hline & 1350 & 200 & 0 & 40 & 0 \\
\hline & 1450 & 220 & 0 & 50 & 0 \\
\hline \multirow{3}{*}{ 中尖部 } & 800 & 330 & 0 & 0 & 0 \\
\hline & 1250 & 680 & 0 & 0 & 0 \\
\hline & 1350 & 770 & 0 & 0 & 0 \\
\hline \multirow{3}{*}{ 迠心部 } & 300 & 80 & 0 & 0 & 60 \\
\hline & 500 & 200 & 0 & 0 & 140 \\
\hline & 1450 & 430 & 0 & 0 & 410 \\
\hline
\end{tabular}

よび根面近心侧部とに力が作用する.

b) 切縁中央部で咬合させると，根面唇側部だけに力 が加わる。

c）切縁谴心部で答合させる場合は，根而唇側部と根 面遠心侧部とに力が加わる。

d）根面唇侧部に加わる力は切縁中头部で艾合したと きがもつとも大きい

以上の笑験結果は，予侕奏䮖において模型について行 なつた实験成績とまつたく同様である.

2）咬合力の大きさと継続俻の根西の各部に加わる力 


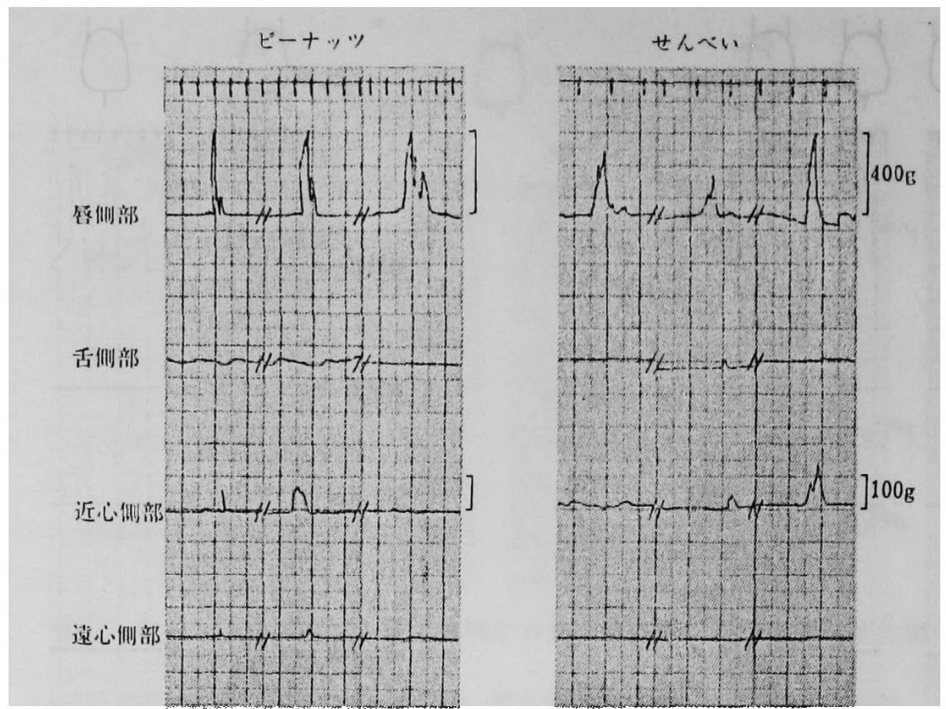

図 9 ピーナッツ抢よびせルベい咬㪿㭙の根面の谷部に加わる力の記録波形

との関倸

a）㕮合力をしだいに大きくしても，才が加わる根面 の部位は1)の実験結果とまつたく同じである.

b）しかし，切縁のどの部位で咬合させても，根而の 各部位に扣わる力の大きさは咬合力が大きくなるにつれ て增加する。

2. ピーナッツおうよびせんべい咬断時に継続画の根面 の各部に加わる力

各被検者にピーナッツおよびせんべいを任意に何度も 咬断させると(図 9 ),

1) どの被検者でも，またどのようなかみ方をして も，つねに根面唇侧部には力が必ず扣わつている。

2) ところが，被検者によつては，また同じ被検者で もそのかみ方によっては, 根面の唇侧部以外の部位にも 力が加わるときがある、

したがつて，ピーナッッでも，せルベいでもその筊断 時には，a）根面唇侧部だけに力が加わる場合もあれば， b）根面の唇侧部と近心側部とに加わるときもある。 ま た，c）まず根面の佦侧部と近心侧部とに, ついで少し おくれて根面の唇側部と遠心側部とに力が加わるときも 認められる.

3）しかし, どの場合でも根面唇侧部に加かる力がも つとも大きい.

4）また，根面に执わる力の記録波形には，2〜3 個 の速続した栜波が認められる.

\section{C. 模型についての実験}

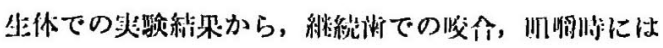

つねに根面唇側部に㗳合力および孟嚯力が集中している ことが明らかになつた。

そこで, 根面唇侧部に加わるこの力がどのような因子 によつて影蠁を受けるかを追究するために，生体での实

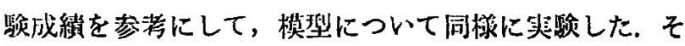
して,つぎのような成緽を得た。

1. 継続断の蒾冠切縁の唇舌的位㯰と継続歯の根面の 各部に加わる力との関倸

継続歯の蒾冠切縁の唇舌的位固が歯軸延長線よりも $3 \mathrm{~mm}$ 唇侧答り，歯杣延辰線上および歯軘延辰線よりも $3 \mathrm{~mm}$ 舌侧寄りにある継続迷の蒌冠到縁に, 舌側方向か ら歯协に対して $30^{\circ}$ の角度で $1 \mathrm{~kg}$ の荷重をばね科りで 加えても，

1）荷重を加える蒾冠切縁の部位と，力の加わる継続 啮の根面の部位との関係は，予備実験および生体での実 験で得られた成績とまつたく同様であつた，すなわち，

a）歯冠切縁近心部に荷重を加えると，根面の唇侧部 と近心側部とに力が加かる(図10).

b）切縁中央部に荷重を与えた場合は，大部分の力は 根面唇側部だけに，そして，一部分の力は根面近心側部 に加わる（図11）.

c）切縁遠心部に荷重を加えるときには，根面の唇側 部と遠心侧部とに力が加わる(図12).

d) そして，根面唇侧部に加わる力は，切䋛中块部に 伍罡を加えたときがもっとも大きい(図13).

しかし,

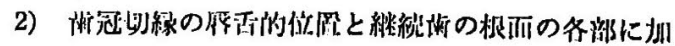




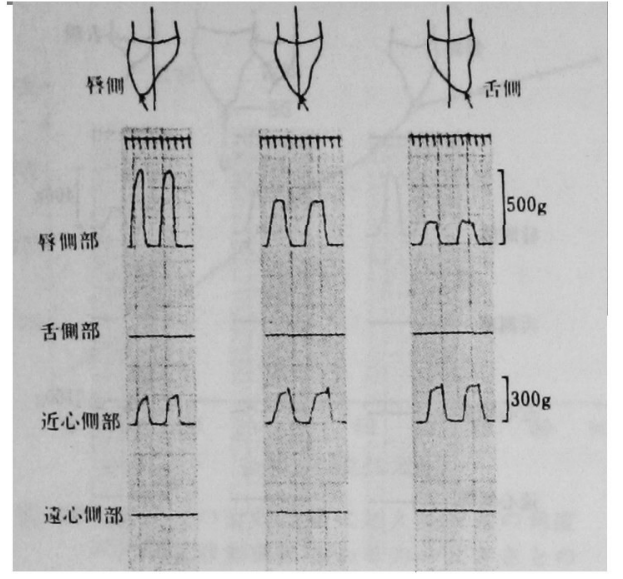

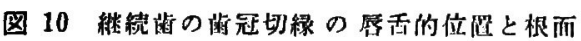
の各部に加わる力の記䟿波形（街自部 位: 切緑近心部)

背冠切緑の唇舌的位置：左; 唇侧管り，

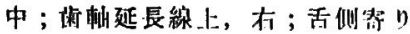

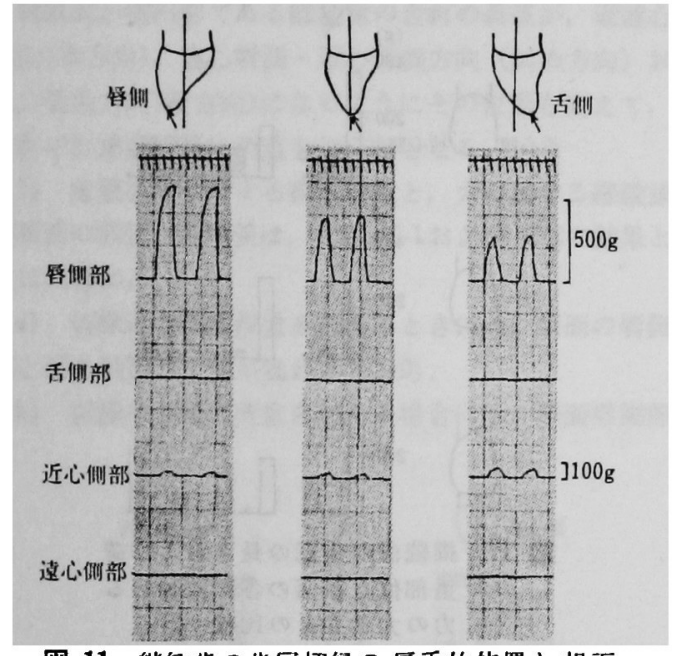

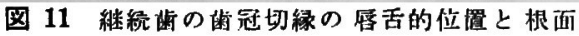
の各部に加わる力の部䟿波形（荷垂饰 位：切縁中央部)

わる力の大きさとの閒には，つぎのような関係が認めら れた(図13).

すなわち,

a）切緑のどの部位に街重を加えても，根面唇仙部に

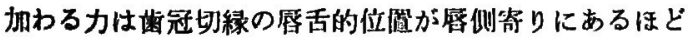
大きい.

b) ところが，根面の近心侧部と遠心側部とに加わる

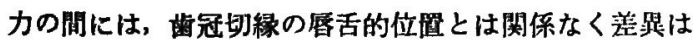
認められなかつた。

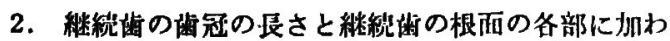

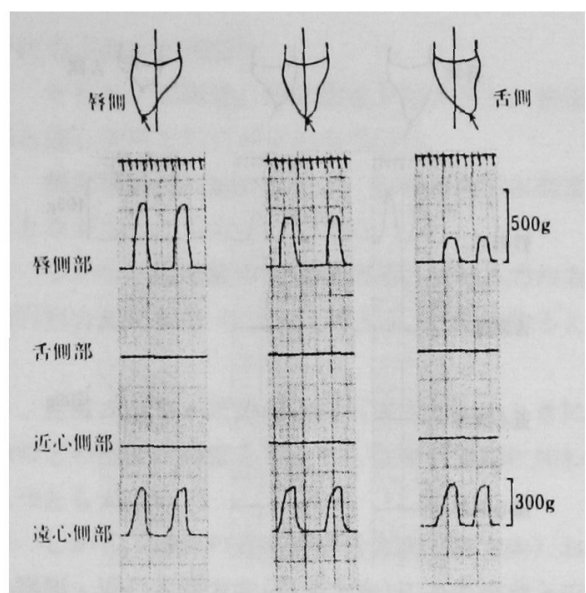

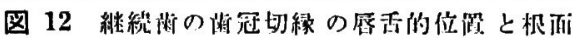

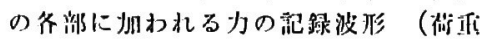
部位：切緑䢙心部)
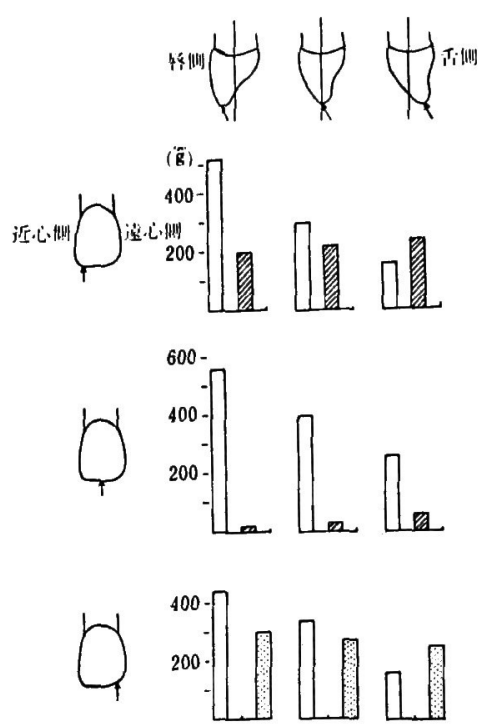

図 13 継絖啮の蒾冠切緣の唇舌的位㽞および 修盾部位と根面の各部に加わる力の大 きさとの比校

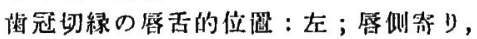
中；粹恻延長線上，存；舌侧箱!

る力との閣係

継続䛧の歯冠の脣さを, $12 \mathrm{~mm}, 9 \mathrm{~mm}$ および $6 \mathrm{~mm}$ に変えても，

1）力の加わる継続歯の根面の部位は, 歯冠切縁の唇 舌的位㯰を変えた場合の実験結果とまつたく同様であ る. すなわち,

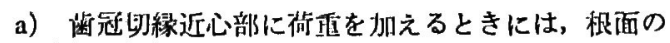




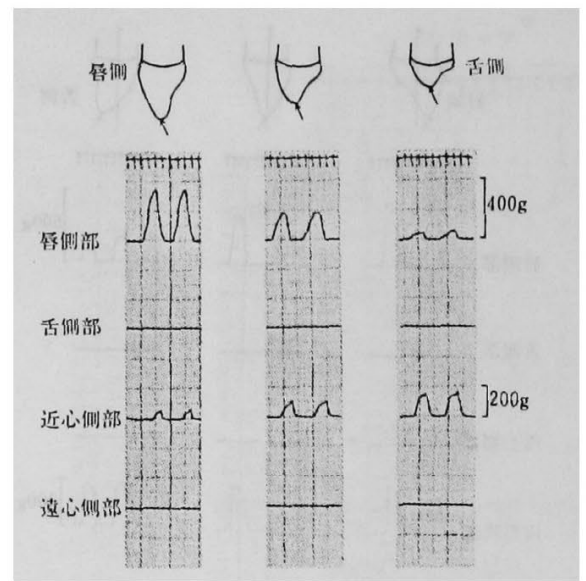

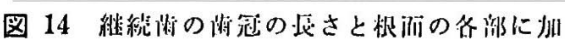

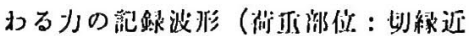
心蔀)

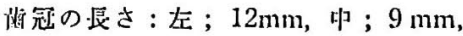
右； $6 \mathrm{~mm}$

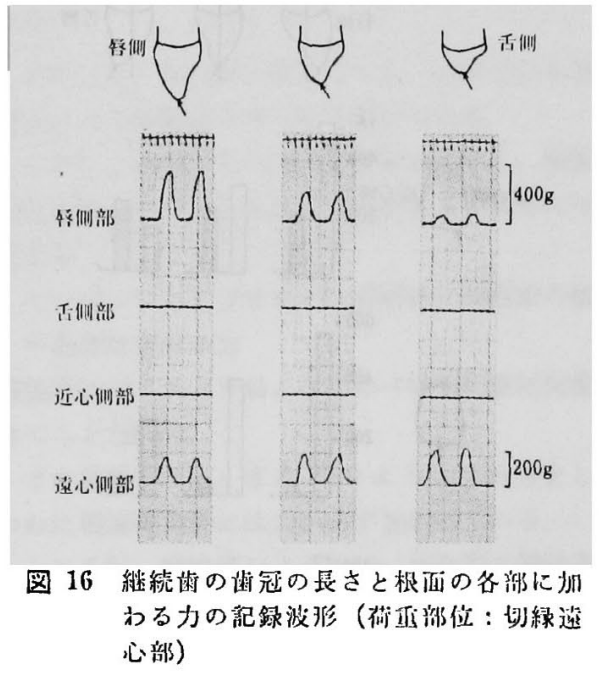

唇侧部と近心侧部とに力が帅わる(図14).

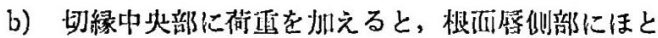
んどの力が加わるが，根西近心倒部にも一部分の力が作 用する (図15).

c）切縁遠心部に荷重を加える場合には，根面の唇側 部と遠心侧部とに力が加わる(図16)。

d）根面屡侧部に加わる力は，划縁中央部に莎重を加 えたときがもつとも大きい(四17).

しかし,

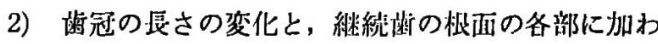
る力の大きさとの関係(図17)は，

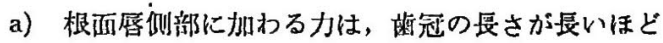

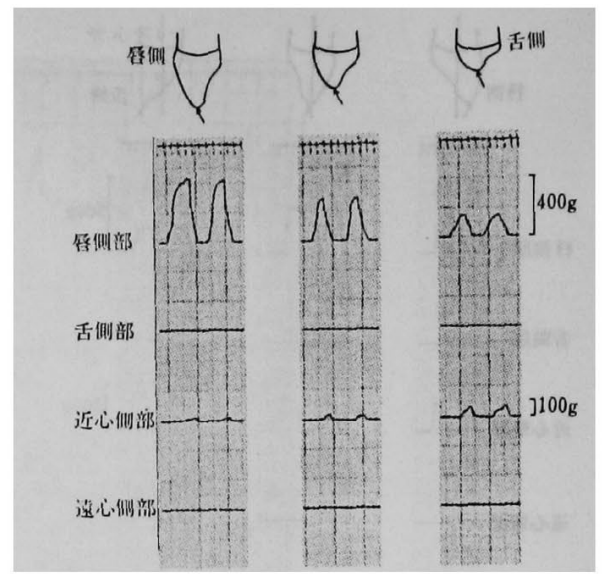

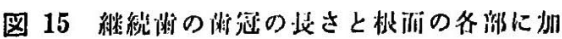

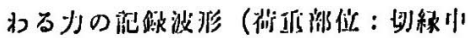
火部)
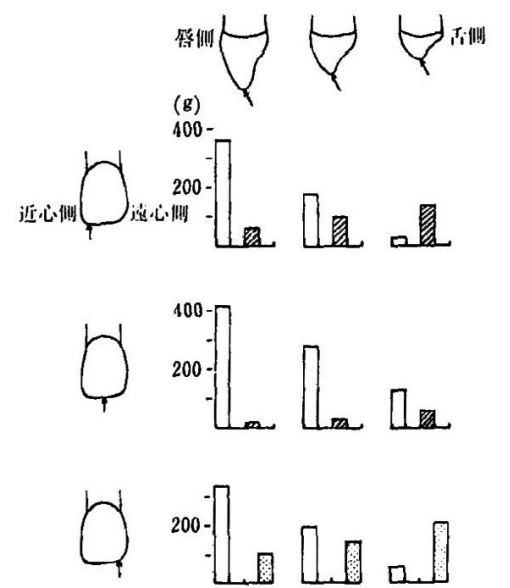

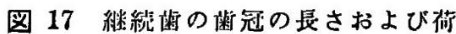
菆部位と根面の各部に加わる 打の大さとの比模

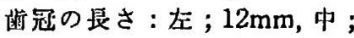
$9 \mathrm{~mm}$, 右 ; $6 \mathrm{~mm}$

大きい.

b) ところが，根圂の近心側部および遠心側部に加わ る力は, 歯冠の辰さが㔫くなるほど小さくなる.

3. 継続歯の菌冠切縁に加える荷重の角度と継続歯の 根面唇側部に加わる力の大きさとの関係

舌侧方向から夦冠切縁中央部に加える荷重の角度を， 歯杫に対して $0^{\circ}$ から $90^{\circ}$ まで変化させて，根面唇側部 に加わる力の大きさを比校すると（図18），

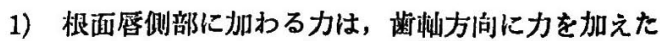
ときがもつとも小さい.

2）そして，萑重を加える角度が齿佃に対して大きく 


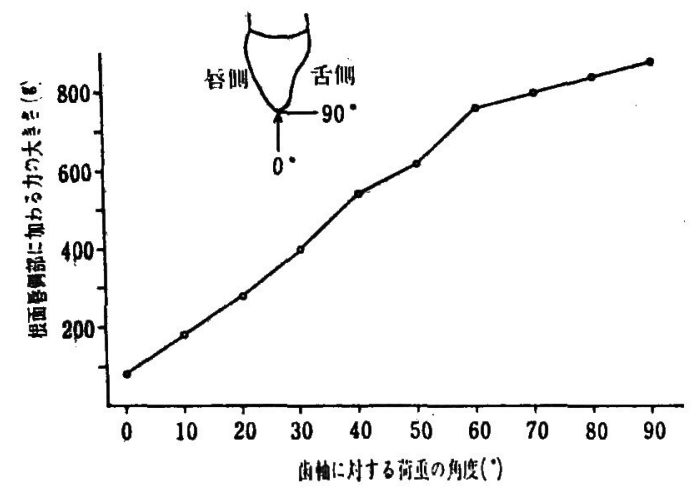

图 18 継続齿の画冠切緑に加える荷重の角度 と根面唇側部に加わる力の大きさとの 䦗掭

なるにつれて，根面唇側部に加わる力は大きくなる.

4. 継続歯の合釘の形態と継続歯の根面の各部に加わ る力との関倸

横渐面が楕円形である継続歯の合釘の長径が，近遠心 方向(横方向)，遠心唇側・近心舌側方向（斜め方向）お よび唇舌方向(縦方向)になるようにその位置を変えて， それぞれ歯冠切縁に荷重を加えたところ，

1) 歯冠切縁に対する荷重部位と, 力の加わる継続歯 の根面の部位との関係は, 実験 C-1およびC-2の結果と ほほ同様に,

a）切縁近心部に荷重を加えるときには，根面の唇侧 部と近心側部とに力が加わる(図19).

b）切緑中央部に荷重を加える場合には，根面唇側部

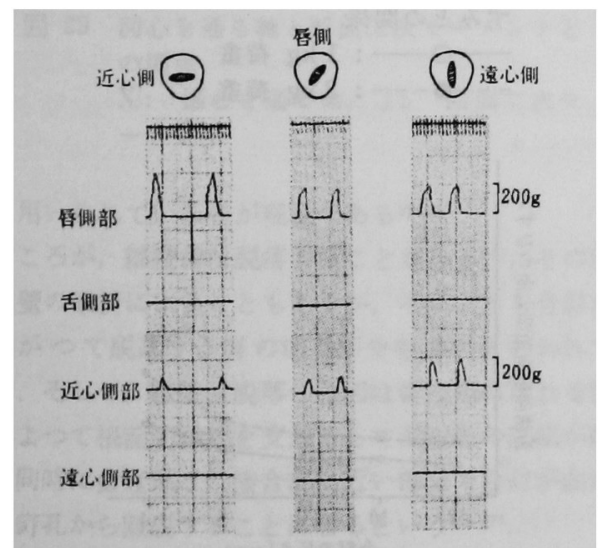

图 19 合猃の形热と根面の各部に加わる力の 轭録波形 (荷重部位: 切緑近心部) 合剑の形热：左；長径が近楝心方问に ある柏円形，中；長径が拈心唇侧方问 加ら近心舌侧方向に向かう桁円形，右； 展径が磨舌的方问にある情队形
だけにカが加わる(図20).

c）そして，切縁遠心部に荷重を加えると，根面の唇 側部と遠心側部とに力が加わる(図21).

d) 根面唇側部に加わる力は，切縁中央部に荷重を加 えたときがもつとも大きい(図22).

2）しかし，継続歯の根面唇側部に加わる力の大きさ と棈円形合釘の長径の方向との関係を比較すると（図 22),

a) 合釷の長径が近遠心方向（横方向）のときには, 切縁のどの部位に荷重を加えても根面唇側部に加わる力 はもつとも大きい.

b）しかし，合釘の長径が唇舌方向（縦方向）およひ 遠心唇侧・近心舌侧方向 (斜め方向)にある場合とでは， 根面唇側部に加わる力の大きさにはあまり差異が認めら

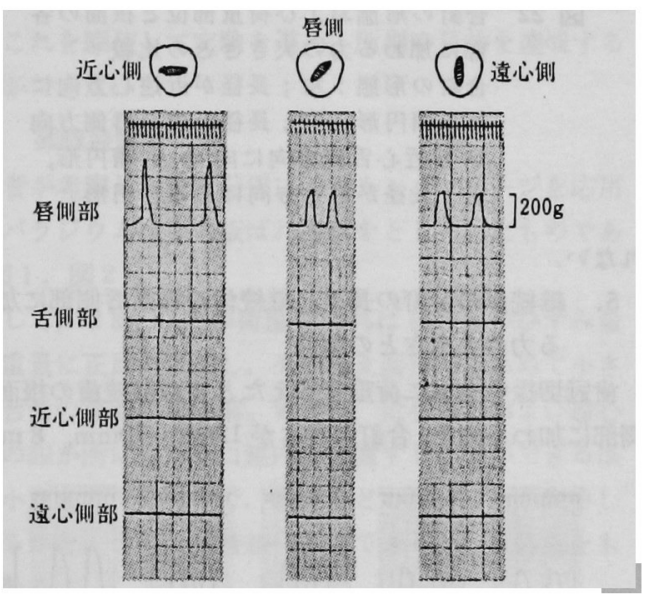

图 20 合釷の形態と根面の各部に加わる力の 記録波形（荷重部位：切緑中央部）

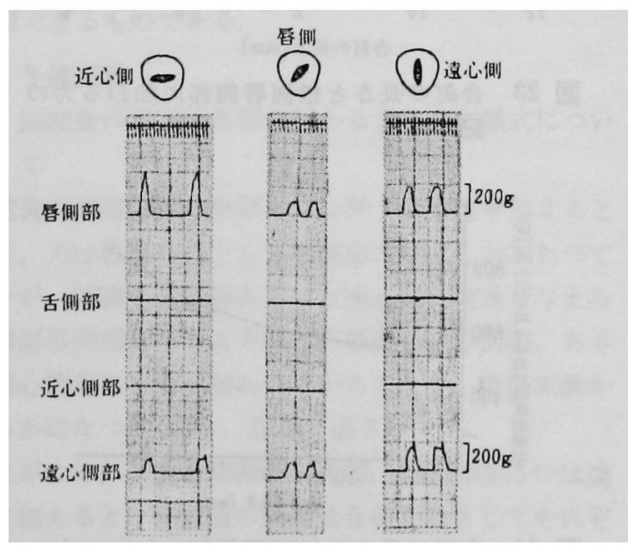

图 21 合猃の形热と极面の各部に加わる力の 記録波形（荷重部位：切緑遗心部） 


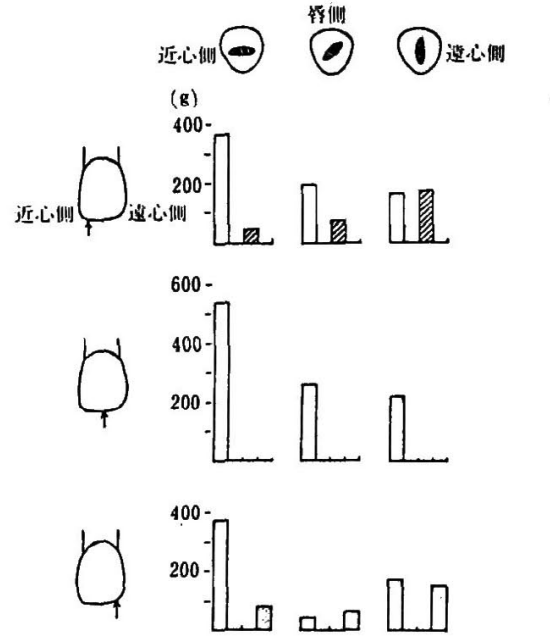

图 22 合钉の形热および荷重部位と根面の各 部に加わる力の大きさとの比較 合猃の形態 : 左 ; 脣径が近遠心方向に ある桶円形，中；長径が遠心唇侧方向 加与近心舌侧方向に向かう棈円形， 右；長径が唇舌方向にある棈円形

れない。

5. 継続歯の合釘の長さと継続歯の根面唇側部に加わ る力の大きさとの関倸

歯冠切縁中央部に荷重を加えたときの継続歯の根面唇 側部に加わる力を, 合釷の長さが $12 \mathrm{~mm}, 10 \mathrm{~mm}, 8 \mathrm{~mm}$,

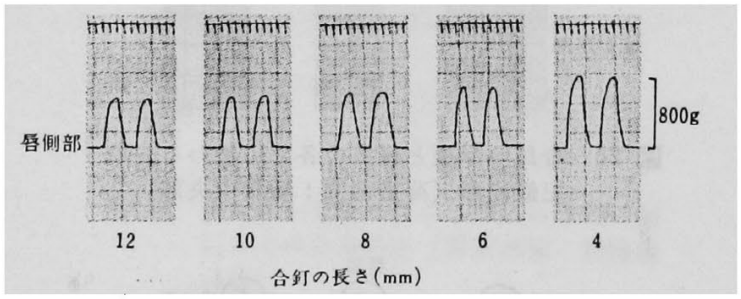

図 23 合釘の長さと根面唇侧部に加わる力の 記録波形

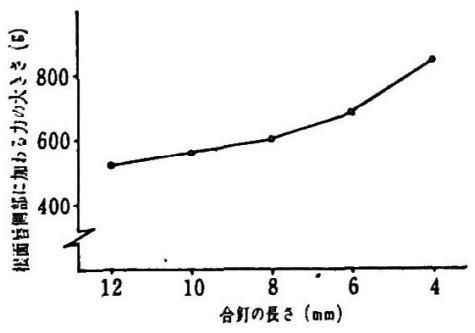

图 24 合釷の長さと根面唇侧部に加わる力の 大きさとの比较
$6 \mathrm{~mm}$ および $4 \mathrm{~mm}$ の場合につケて比較すると, $12 \mathrm{~mm}$ のときがもつとも小さく，合釷の長さが短くなるほど根 面唇側部に加わる力は大きくなることを認めた（図23， 図24).

6. 合釘の長さと齔根歯顓部表面のひずみとの関係 舌側方向から齿軸に対して直角に, 合釘に $1 \mathrm{~kg} お よ$ び $2 \mathrm{~kg}$ の荷重をばね科りで加えると(図25，図26)，

1）唇側齿根苗竍部表面には圧縮ひずみが，吉側齿根 䍈䫓部表面には引つ張りひずみが生ずる。

2）合钉の长さを短くするほど，唇側および舌側歯根

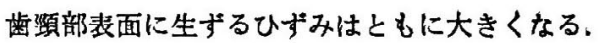

3）加える荷重の大きさを $1 \mathrm{~kg}$ から $2 \mathrm{~kg}$ にすると， 蓉側および舌側歯根歯頸部表面のひずみともに等差級数 的に增加する傾向を示す.

\section{総括および考察}

わが国では, 前歯部の無跹処置歯の補悢には継続歯が

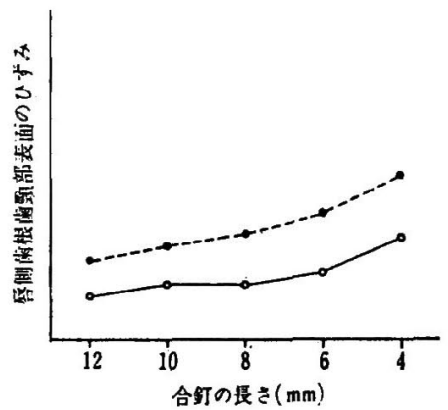

図 25 合釘の艮さと唇侧齿根齿㛲部表面のひ すみとの関俰
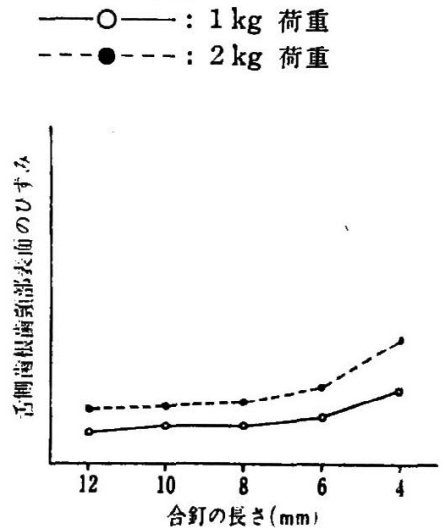

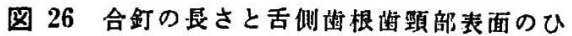
ずとの関係

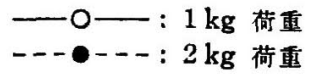



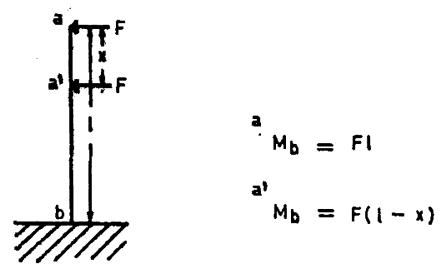

图 27 片持はりの曲げモーメント

$a ：$ 自由端, $b$ : 固定端, $M$ ：曲げモーメン 卜, F：荷重

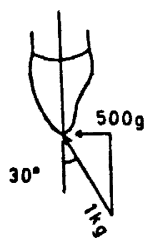

$1 \mathrm{~kg} \times \sin 30^{\circ}=500 \mathrm{~g}$

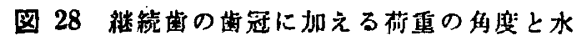
平分力との関係
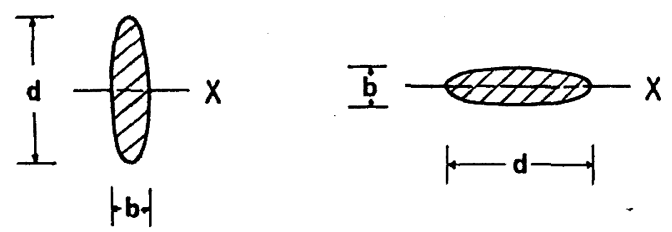

$J=\frac{\pi b d^{3}}{64}$

$J=\frac{\pi b^{3} d}{64}$

图 29 図心を通る柚と断面二次モーメントと の腈係

$\mathrm{X}$ ：图心を通る柚，J：断面二次モ ーメント

多く用いられているのが現状である88-92).

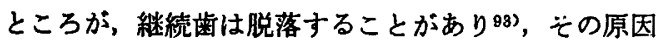
が根壁の破折によることもあるが，それよりも合釘が折 れ曲がつて脱落する例 のほうがやや多いといわれてい る90). そして, 継続歯脱落の原因は歯冠部に加わる咬合 力によつて根面周縁部を支点として歯冠部の回耺が起こ り，同時に迤冠部との接合部に近い部分で合釷が曲がつ

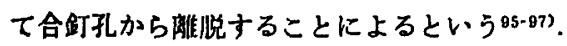

また，コアーを施したジャケットクラウンでは，唇側 の辺緑部で般折することがあるが，それは支点となる根 面周縁部に咬合力が集中することに基因すると考えられ 㝵(6),

しかし、このような継続歯あるいはコアーを施したジ
ヤケットクラウンの破折や脱落を起こさせる力について 検討した報告は少ない。

そこで，著者は被検者に継続歯でもつとも作製瀕度の

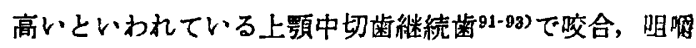
させ, 継続崡を介して, その支台歯の根面に加わる力の 分布様式から, 継続歯やコアーの脱落の原因を力学的に 考察しようと考えて，この実験に着手した.

ところが，補緅支台歯の応力分布を模型について検討 した実験はきわめて多い.しかし，従来からこの種の実 験では，光弾性にょる方法が多く用いられ，ストレイン ゲージ法によつて測定した実験には, Kydd, W. L. et al. (1964) ${ }^{67)}$, Henderson, D. and Seward, T. E.

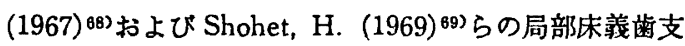
台齔についての報告があるだけである.

著者は、ストレインゲージを応用した受圧装直を考案 し，これを駆使して実験を進め，所期の目的を達成する ことができた.

\section{A. 実験装置}

著者が考案した受圧装直は，ストレインゲージを応用 したパラジウム合金の板ばね機構をとり入れたものであ る(図 1, 図 2).

そして， $2 \mathrm{~kg}$ 以内の荷重であれば板ばねのひずみ量 は荷重量に正比例するし, そのうえ面積のきわめて小さ い支台歯の根面の唇侧部, 舌侧部, 近心侧部および遠心 側部の四か所にしかも口腔内で設置することができるほ ど微小なものであるので, 根面のどの部位に力が集中し ているかを，きわめて精細に测定できるという特徵をも つている.

したがつて，この受圧装置は根面の各部に加わる力の 分布様式を明らかにするという，本実験の目的には十分 に利用できるものである.

\section{B. 予備実験}

1. 継続蒾の根面の各部に加わる力の分布様式につい $\tau$

継続歯の歯冠切縁中央部にばね科りで荷重を加えると きには，力は根面のほとんど唇侧部だけにしか加わつて いないが，切縁の近心部あるいは遠心部に荷重を与える と, 根面唇侧部のほかにそれぞれ根面の近心側部，ある いは䢤侧部にも力が加わつていることが，予佛実験か ら明らかになつた(図 5, 図6,表 2).

したがつて, 荷重を切縁の中央部, 近心部あるいは遠 心部に加えると, 継続歯の歯冠は合釘を軸としてそれぞ れ攵側に，近心側にあるいは遠心侧に傾斜することがわ かる. 
これと同し現象は天然齿において，その苳冠切縁に荷 重を加えたときにも認められている。すなわち，Ka-

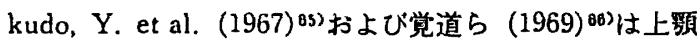
中切蒛抜去歯の歯冠の唇面, 舌面, 近心面および遠心面 に荘軸方向にストレインダージをはり，齿冠切縁の近心 部，中央部および遠心部の各部に荷重を加えたときに現

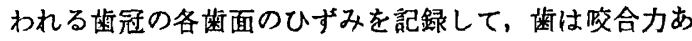
るいは勗啴力によつて力の加わる方向にひずむことを証 明している。

このように，咬合力や䏣啹力が蒾根によつて受容され る天然歯歯冠でさえも，力を加える部位によつて近心侧 や遠心側にひずむのであるから，まして歯根上りも細い 合釷によつて管合力や阻啁力が支持されている継続歯に おいては，その歯冠の傾斜する傾向が天然歯に比べて大 きいのは当然のことである.

2. 継続㐘の根面の各部に加わる力の大きさについて 根面唇側部に加わる力は切縁の近心部，あるいは遠心 部に荷重を加えるときょりも，切縁中央部に加えるとき のほうが大きい(図 5 , 図6，表 2 ).

このことは, 切縁中央部に加えた荷重は, その全部が 合釷を直接唇側方向に曲げようとする力として傎くのに 対して，切縁の近心部あるいは遠心部に荷重を加える場 合には，荷重の一部は根面のそれぞれ近心側部あるいは 遠心側部で分担されて，合釘をねじるような力として作 用するので，根面唇側部に加わるカが淢少することに基 因している.

3. 継続歯の合釬と合釘孔とのセメント装着の影響に วけて

継続歯の合釷を合釘孔にセメント装着したときには， セメント装置前に比べて根面の各部に加わる力はやや減 少している.

しかし，セメント装置前後における根面に加わる力の 減少率は，歯冠切縁のどの部位に荷重を加えても，また 根面のどの部位に力が加わつてもつねにほぼ一定である し，根面に加わる力の分布様式にも七メント装着の前後 においてまつたく変化が認められない。

したがつて，セメント装着の有無は実験結果に対して は，それほど大きな影響を与えるものではないことは明 白である(図 5 , 図6, 表 2 )。

C. 生体での実験

1. 咬合力測定器を咬合させたときの継続歯の根面に 加わる力について

1）継続歯の根面の各部に加わる力の分布について 咬合力测定器を継続㐘歯冠の切縁近心部で咬合させる
と根面の居侧部と近心侧部とに，また切緑中央部で览合 させるときには根面唇侧部だけに，そして切緑遠心部に おける吹合では，根面の唇侧部と遣心侧部とにそれぞれ 力が加わる. 寸なわち, 根面㻺侧部には切縁のどの部位 で烄合させても力が加わつている(図 7，表 3).

2）継続苗の根面の各部に加わる力の大きさについて 咬合力をしだいに大きくしても根面に加わる力の部位 は，1\%の場合とまつたく同栐であるが，根面の各部に加 わる力の大きさは 切緑のどの部位で咬合させても唂合 力が大きくなるにつれて增加する(図 8，裴4)，

また，根面唇側部に加わる力は同し大きさの咬合力で も切縁中央部で咬合させたときがもつとも大きい(図7， 表 3 ).

2. 食品を勗嶰させたときの継繶歯の根面に加わる力 につけて

1）継続歯の根面に加わる力の記録波形の分析

ピーナッッまたはせんへい゙を継続歯で峧断させるとき には, 根面唇側部だけに咀嚼力が加わる場合もあれば, 根面の唇側部と近心側部とに力が作用するときもあり また初めに根面の唇側部と近心側部とに, ついで少しお くれて根面の唇側部と遠心側部とに咀嘅力が加わる場合 などもみられた(図 9).

そして，根面唇側部だけに力が加わる場合は，齿冠切 縁中央部で咀嶰したときであり，また根面の唇側部と近 心側部とに力が作用するときには，切縁近心部で咬合し たことを示し，最初根面の唇側部と近心側部とに，つい で少しおくれて根面の唇側部と遠心側部とに力が加わる 場合は初めに切緑近心部で, つづいて切縁遠心部で咬断 したことを現わしている．食品咀洔時にこのような現象 が認められるのは，食品の咬断時に下影が左右に動く ことが原因であろう.

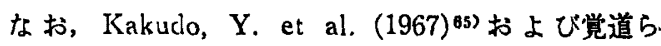
(1969) ${ }^{86)}$ によると，ピーナッッ，クラッカーあるいは岩 おこしのような咬断時に破砕される食品を咀㛀するとき

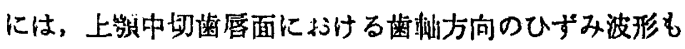
clear cut であるという.だから食品の咀噂時に継続齿 の根面に加わる力の記録波形に $2 \sim 3$ 個の連続した棘波 が羿められたといら著者の実験結果は，食品破碎時や齿

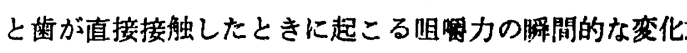
に基因するものであると考えられる.

2）継続歯の根面に加わる力の方向について

継続菌で咬合力測定器を咬合させたときでも，また食 品を勗啊させたときでも，根面の唇侧部，近心例部ある いは遛心侧部，とくに根面唇側部にはつねに大きな力が 
加わつているが，根面舌侧部にはどのようなときもまつ たくカが㑬いていない.このことは合釷が合野孔内で沈 むことなく，つねに歯冠が合釘を軸として辰側，近心側 あるいは遠心側の方向，とくに唇側方向に強く傾斜して いることを示している。

このように，咬合や阻洔時には唇側方向一の大きな水 平分力が継続歯歯冠部に扸いていることは，上下頻の中 切墦がどちらも唇側方向に㑯斜しているという形態学的 特性99-103) や Parfitt, G. J. (1961) 104) の茵の機能時の 動きについての報告, あるいは Kakudo, Y. et al. $(1967)^{65}$ おょよび党道ら (1969) ${ }^{66}$ )の咬合, 咀㕰時の天然歯 の歯冠部のひずみに関する実験結果からも推測されるこ とであるが，著者の実験において実証されたわけであ る.

だから，従来からいわれている上㯋中切歯の補経物の 設計や作製にあたつては，舌側方向から唇側方向へ加わ る水平分力を十分に考虑しなければならないということ を,なおいつそう强調できる根拠が著者の実験によつて 与えられたといえる.

しかし，継続歯の根面唇側部に加わるカがどのような 因子によつて影響を受けるか検討しなければならない. したがつて,この点を詳細に究明するために, さらに模 型実験を行なら必要性と意義が十分に認められる.

D. 模型についての実験

1. 継続菌の崡冠切縁の唇舌的位置および歯冠の長さ と継続菊の根面の各部に加わる力との関係につい $\tau$

継続歯の蒾冠切緑の唇舌的位直が唇侧寄りにあるほ ど, 継続歯の根面唇倒部に加わる力は大きく, 舌側奇り にあるほど小さい，しかし，根面の近心侧部および遠心 側部に加わる力は, 歯冠切縁の唇舌的位置によつてあま り影響を受けない(図13).

また，歯冠の長さが短いほど根面唇側部に加わる力は 小さいが, 根面の近心側部および遠心側部に加わる力 は,これとは逆に歯冠の長さが短くなるほど大きくなる 傾向を示している(図17).

以上の事実から，継続菌に咬合力あるいは咀喥力が加 わるときには, 合釘孔内にある合釘部分を固定端とし, 歯冠切縁を自由端とした片持はりの曲げモーメントが継 続齔に生じていることが想像できる.

図27に示すように，一端を固定したはりの自由端 a に雀中苝近 $\mathrm{F}$ を加えたときの，はりの断面における曲げ モートメントは，固定端 b において良大（F1）である

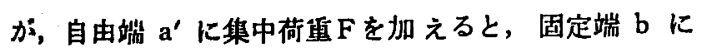

おける曲げモートメントは F(1-x) に減少する. した がつて，曲げモートメントが最大の固定端すなわち合釘 部分, が曲がつて根面唇側部に力がかがり, 歯冠の長さ が短くなるほど根面唇側部に加わる力は小さくなり, 根 面の近心側部および遠心側部に加わる力は逆に大きくな るのであると考えられる.

また，片持はりに扔いては，曲げモーメントははりの 固定端において最大值を示すので，はりの断面が一様で ある場合には固定端がいちばん弱い。まして，継続歯で は歯冠断面よりも合釘断面のほうが細く，はりの固定端 だけがとくに紐い片持はりであるので，固定端はよりい つそう弱くなる. したがつて, 日常の臨床において継続 歯の合釘が折れ曲がつて脱落することがあるのは, 固定 端に相当する合釘部分に曲げモーメントや，せん断力が 㰾くことがその原動力であるといえる.

石井 (1968) ${ }^{863}$ はジャケットクラウンの菌冠部模型を用 いて，その破折機構を検討した実験結果から，コアーを 施したジャケットクラウンの破折の原因を推測している が、コアーを施したジャケットクラウンは合釘を有する

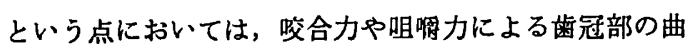
がり方が，継続歯の場合と同じと考えてよい，だからコ アーを施したジャケットクラウンの唇側辺縁部に生ずる 破折は継続歯について解明した著者の実験結果と, まつ たく同様の機序によつて起こるといえる.

2. 継続歯の歯冠切縁に加える荷重の角度と, 継続歯 の根面唇側部に加わる力との関倸について

継続歯の歯冠切縁中央部に荷重を舌側方向から唇側方 向へ加えるときには, その荷重の方向が歯軸方向に近う くほど, 継続歯の根面唇側部に加わる力は小さくなり, 逆に遠ざかるほど大きくなる(図18).

そこで, 舌側方向から苗軸住対して $30^{\circ}$ の角度で $1 \mathrm{~kg}$ の荷重を加えた場合の水平分力を計算すると, $1 \mathrm{~kg} \times$ $\sin 30^{\circ}=1 \mathrm{~kg} \times 1 / 2=500 \mathrm{~g}$ となる(図28). また, 角度が $45^{\circ}$ の場合は約 $707 \mathrm{~g}\left(1 \mathrm{~kg} \times \sin 45^{\circ}\right), 60^{\circ}$ のときには 約 $866 \mathrm{~g}\left(1 \mathrm{~kg} \times \sin 60^{\circ}\right)$, である. だか, 荷重方向が 水平方向に近うくほどすなわち菌軸に対する荷重の水 平分力が大きくなるほど, 合釘における唇側方向への曲 げモーメントが大きくなる結果, 根面唇側部に加わる力 が增加するのであろう。

3. 継続歯の合釷の形热と, 継続歯の根面の各部に加 わる力との関倸について

一般に, 合猃の形態は歯根の横断面にほぼ相似形であ るか，あるいは展舌的に楕円形または卵円形であること が合理的である84,87)といわれている，また，棈円形の図 
心を通る軸侄対する湐面二次モーメントJ $(\pi \mathrm{bd} 8 / 64$,

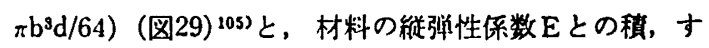
なわち“曲げこわさ”JE の值が大きいほど曲がりにく (108).このことを合釷に当てはめて考えると，横断面 が㨢円形である合釘では，曲げこわさは長径方向 (d9) から加圧する場合のほうが短径方向 $\left(b^{3}\right)$ から加圧する ときよりも大きい，したがつて，咬合力や阻嘲力の加わ るおもな方向が唇舌方向であることを考虑すると，合釷

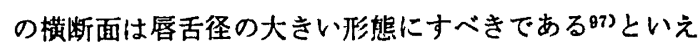
る.

ところが，その長径の方向がそれぞれ近遠心方向, 遠 心唇側方向から近心舌側方向および唇舌方向にある棈円 形合釘について，継続画の根面の各部に加わる力を比较 検郡した著者の実験では，歯冠切縁のどの部位に荷重を 加えても, 根面唇侧部に加わる力は合釷の長径が近遠心 方向にあるときがもつとも大きくなり，合釘の長径を唇 舌方向におくのがよいという先人の意見に一致した知見 を得た．しかし，合釷の長径を斜め（遠心唇側・近心舌 侧方向）においたときも，唇舌方向にしたときと根面唇 側部に加わる力にはあまり差は認められない(図22).

4. 継続歯の合釘の長さと, 継続歯の根面唇侧部に加 わる力の大きさとの関係について

継続歯の合釘の長さを短くするほど，根面唇側部に加 るわ力は增加する(図24).このことはつぎのような機序 によると考えられる.

合釘の長さの変化と合釘を支えている合釘孔壁の単位 面積あたりに倕くカとの関係, すなわち合釘の長さと歯 根齿顕部表面のひずみの変化との関係を調べると, 同し 大きさの力を合釘に加えても合釘孔内にある合釘の長さ が短くなるほど，歯根歯頸部表面のひずみは增加する (図25, 図26).このことは蒛根歯顆部に加わる応力が大 きくなることを示すものであり，継続歯の歯冠に力を加 えた Koller, K. C. (1954) ${ }^{107)}$ の成續も一致している. したがつて，合釘孔内の合釘の長さを短くすると合釘を 支えている合釘孔壁の単位面績あたりに働く力が増加 し，根面唇側部に加わる力が增大寸るのである.

予備実験においても，継続歯をセメント装着したとき のほうが，セメント装着しないときよりも根面に加わる 力がやや減少するという結果(図6)を得ているが，この ことも合釘と合釘孔壁との問腺にセメントが満たされた ために，合釘を支えている合䟓孔壁の単位面績あたりに 作用する力が诚少したことによるものであるといえる。

また，セメント装着した合釘の引き抜き試験を行なつ た花村 (1964) 108)および Colley, I. T. et al.(1968) 109)
の報告によると，合猃を引き报くときの倚重の大きさ， すなわち合釷の保持力は合釷が長いはど大きいといつて いるが，この実㔀結果も合釘は長いほど脱落しにくいと いら点では応力分布の立場から検討した著者の実験成績 に一致している.

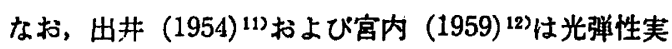
験により，継続歯の歯冠に舌側から荷重を加えると，答 側には圧縮応力が, 舌側には引つ張り応力がみられ, 根 の㻺側歯顓部および舌側歯根尖 $1 / 3$ 部, すなわち合钉の 先端部に応力が集中し, 継続歯は歯頸部を支点として䫅 杆荤動をしていることがうかがえると述へているが，こ の所見も抜去歯歯根についてストレインゲージ法によつ て行なつた著者の実伢による知見と同じである.

\section{結論}

継続歯の根面に加わる咬合力および咀啁力の大きさ， 方向および分布様式と継続歯の歯冠の長さや㑯斜，ある い:合釘の長さや形態などが，継続歯の根面に加わる力 にどのような影響を与えるかを，生体ならびに模型につ いて検討し、つぎのような結諭を得た。

1. ストレインゲージを応用し，上影中切歯継続画支 台歯の根面の唇側部, 舌側部, 近心側部および遠心側部 に加わる咬合力や咀鹏力の大きさから，継続菌の根面に 加わる力の方向および分布様式を，直接測定できる受圧 装直を考案した.

2. この装渎を被検者の継続歯支台歯に装着して，咬 合力測定器を継続菊の歯冠切縁で咬合させたときと，食 品を咬断させた場合とについて测定した結果，

1) 咬合力測定器を的冠切粶近心部で焧合させると， 根面の唇側部々近心侧部とに, 切縁中央部で咬合すると きには根面屡側部だけに，切縁遠心部での咬合では根面 の唇側部と遠心側部とに力が加わる.

2）根面㻺側部に加わる力は, 切緑中央部で咬合した ときがもつとも大きい.

3）咬合力を大きくすると, それに伴つて根面のどの 部位に加わる力も增加する.

4) ピーナッツあるいはせんべレを咬断させても、根 面唇侧部にはつねに大きな力が加わる。 また，根面に加 わる力の記録波形には，2３個の連統した棘波が誌め られる.

5）以上のことから, 継続歯での咬合, 勗啲時にはつ ねに根面辰側部に力が集中することが明らかとなつた。

3. そして, 根面㻺侧部に加わる力の大きさが継続些 のどのような因子によつて影郘を受けるかを迫究するた 
めに,さらに、模型について実倹した結果，継続歯の根 面唇侧部に加わる力は,

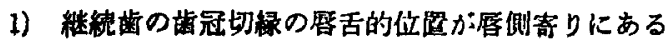
ほど大きくなる.

2）継続㐘の歯冠の長さが長いほど大きい.

3）継続歯の齿冠切緑に舌側方向から加わる荷重の方 向が，画檕に近うくほど小さくなる.

4) 継続歯の棈円形合釘横断面の舆径方向が，唇舌方 向にあるときが小さい。

5）継続歯の合釷の長さが長いほど小さい.

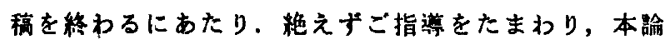
文のご校閲をいただいた小森富夫教授ならびに本学生理

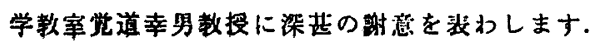

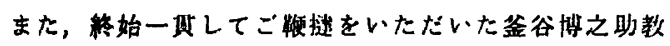
投扰よび種々ご協力くださつた教空員各位や大学院学生 諸氏に感微いたします。

この論女の要旨は，第56回日本補緅菌科学会（昭和 44 年10月13日，大阪）ならびに第 170 回大阪苗科学会例会 （昭和44年11月 8 日，大阪）で発表した。

\section{文献}

1) Zak, B.: Photoelastische Analyse in der orthodontischen Mechanik, Z. Stomatol., 2237, 87-103, 1935.

2）矢帛忠夫, 三宅直晴, 原学郎ほか：戉牙の光弹 珄実领 (第 1 報)，苗科学報，53:537-540, 1953.

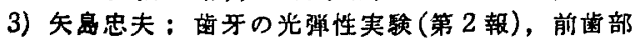
断面について，齿科学報, $54: 121-130,1954$.

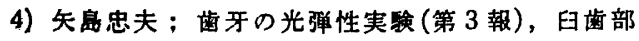
断面について, 菌科学報, $54: 323-332,1954$.

5）矢島忠夫歯牙の光弹性実験（第 4 報），歯槽骨上 秝の下降に上る歯牙の応力変化について，歯科 学報, $54: 365-368,1954$.

6）官内孝雄, 久保田英雄 : 药牙の三次元光强性実 雅方法について，齿科学報， $57: 55-59,1957$.

7）官内素雄：藏牙の三次元光强性実験(第 1 報), 前齿の静力学的考察, 背科学報, $59: 81-94$, 1959.

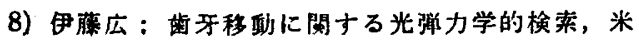
子医勍, $10: 80-98,1959$.

9) 本間葛平, 本間正己, 重内宏微ほ加：上歌中切

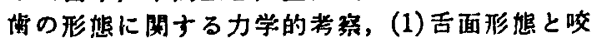
合の閔係についての力学的考察, 度応医学, 37 : 33-40, 1960.

10）本間蓄平, 本間正己, 田村宽之ほか：上䫑中切 㘬の形热に関する力学的考察 (2) 增路的变形に つ以て, 齿科学報, $60: 42-49,1960$.

11) 出井羲教：崡冠補経物支台齿の力学的考察（第 1

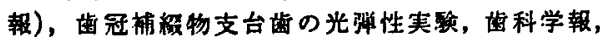

$54: 411-420,1954$

12）宮内孝雄：歯牙の三次元光弹性実弱（第 2 報）, 迷冠補緅物支台歯の静力学的考察, 梅科学報, $59: 306-313,1959$.

13) Colin, L., Kaufman, E. G. and Papirno, R. : Stress concentrations in full crown restora. tions, N. Y. State Dent. J., $29: 370-373,1963$.

14）中林靖夫：全部鋳造冠支台菌の各形態の力学的 研究(第 1 報)，被緅誌，11:88-93，1967.

15) Motsch, A. und Gauss, O.: Spannungsoptische Untersuchungen über Frontzahnbrückenanker, Dtsch. zahnärztl. Z., $24: 797-802$, 1969.

16）大多和彦一：鵒（Clasp Rest）の歯牙に及は ナ影幦にっいて，第一報，主応力線について (Lines of principal stress) (その1), 㙁科学報, $55: 329-334,1955$.

17) 大多和彦一：鈎 (Clasp Rest) の齿牙に及结 寸影帮について，第一報，主応力線について (Lines of principal stress) (完), 茂科学報, 55 : 395-402, 1955.

18）大多和彦一：钩 (Clasp Rest) の歯牙に及ほす 影製について，第 2 報, 周辺応力の分布につい $\tau$, 歯科学報, $55: 413-419,1955$.

19）井上好夫：Clasp Occlusal-Rest の菌牙並びに

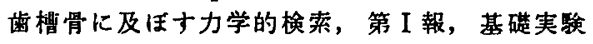
にっいて, 米子医誌, $10: 318-332,1959$.

20) 井上好夫： Clasp Occlusal-Rest の椔牙並びに

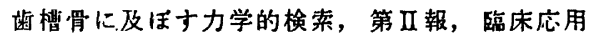
面の力学的学察について, 米子医誌, $10: 333-$ $338,1959$.

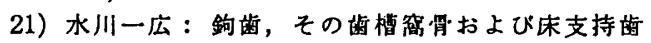
槽缇骨にあらわれる咬合荷重の三次元的光弹性 研究(その 1), 補紩詰, $9: 183-202,1915$.

22）水川一広：鉤歯，その歯槽窗骨抢上び床支持落 慒堤骨汇あらわれる咬合荷重の三次元的光弹性 研究 (その 2), 補緅誌, $10: 26-38,1966$.

23）渡辺孝雄：金属インレー简洞の光弹性実験によ 万静力学的考察 (その 1$)$, 毞科学報, $55: 376-$ $381,1955$.

24）渡辺孝雄：金属インンー简洞の光弹性実験に上 る静力学的考察 (その 2 ), 歯科学報, $56: 65-70$, 1956.

25）波辺孝雄：金属インレー简洞の光弹性実験に上 る静力学的洘察 (その 3 ), 婳科学報, 56 : 107一 $116,1956$.

26) Granath, L-E.: A technique of photoelasticity employed in comparative dental investigations, Odont. Rev., $14:$ 136-144, 1963.

27) Granath, L-E.: Phothelastic studies on certain factors influencing the relation between cavity and restoration, Odont. Rev., $14: 278-$ 293, 1963.

28) Granath, L-E.: Photoelastic studies on occlusal-proximal sections of Class II restora- 
tions, Odont. Rev., $15: 169-185,1964$.

29) Granath, L-E.: Further photoelastic studies on the relation between the cavity and the occlusal portion of Class II restorations, Odont. Rev., 15 : 290-298, 1964.

30) Granath, L.E.: The photoelastic determination of internal stress in Class II restorations, Odont. Rev., $15: 349-365,1964$.

31) Davidson, G. B. : A method for three-dimensional photoelastic stress analysis of the remaining tooth structure associated with various cavity preparations, J. dent. Res., 43 : $43: 912,1964$.

32) Schreiber, S. und Motsch, A.: Kritische Untersuchungen der klassischen Kavitätenpräparationsregeln mit Hilfe spannungsoptischer Verfahren, Dtsch, zahnärztl. Z., 23 : 171-178, 1968.

33) Johnson, E. W., Castaldl, C. R. and Wysocki, G. P.: Stress pattern variations in operatively prepared human teeth, studied by three-dimensional photoelasticity, J. dent. Res., 47 : 548-558, 1968.

34）毛利邦雄, 細川真雄, “松浦智二：義画床に加わ る咬合圧の研究, 補緅誌, $5: 230,1961$.

35) Klötzer, W. : Zur Prothesenwiederherstellung: Wege zur Minderung der Bruchanfälligkeit der Kunststoffprothesen, Dtsch. zahnärztl. Z., 18 : 961-967, 1963.

36) Klötzer, W.: Spannungsoptische Festigkeitsuntersuchungen einiger Prothesentypen, Dtsch. zahnärztl. Z., 19 : 375-384, 1964.

37) Klötzer, W.: Über polarisationsoptische Untersuchungen an Prothesenmodellkörpern : Dtsch. zahnärztl. Z., 21 : 894-901, 1966.

38）久保田英雄：有床義㳡に书ける人工齿と齿榑頂 との位置的関保について(その 1$)$, 齿科学報, $59: 377-384,1959$.

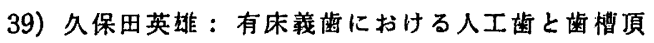
との位圈的関保比っけて(完), 速科学報, 59 : 490-496, 1959.

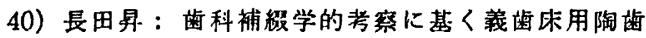
の光弹性実馀 (その 1 ), 婳科学報, $56: 415-423$, 1956.

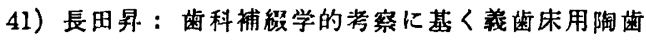
の光弹性实歌 (完), 啮科学報, $56: 475-484$, 1956.

42）宮内孝雄，久保田英雄，関根弘ほか：クラスプ

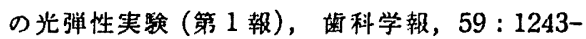
1244, 1959.

43）河合生治郎，小室史郎，奥野善彦ほか：鉤の光 弹性に上万研究, 補緅誌, $\cdot 5: 234,1961$.

44）村松䉆良，安達和子：切り口を有する変断面円 䍗の所げ (cast clasp 設計への一等与), 萄科理 工志, $3: 51-55,1962$.
45）村松第良，安達和子：Cast Clasp の光弹性的 応力解析, 齔材研報, $2: 484-490,1963$.

46）村松筑良，安遠和子：Cast Clasp の光猚性的応 力解析 II，苗科理工誌，5:152-158，1964.

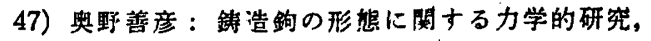
大阪大学藏学橦, $13: 341-352,1968$.

48）久保田英堆, 宮内孝雄：パラタルバーの静力学 的考察，海科学報，57:125-129，1957.

49) Walton, C. B. and Leven, M. M. : A pte. liminary report of photoelastic tests of strdin patterns within jacket crowns: J. Amer. dent. Ass., $50:$ 44-48, 1955.

50) Pettrow, J. N. : Practical factors in build. ing and firing characteristic of dental porcelain, J. pros. Dent., $11: 334-344,1961$.

51) Lehman, M. L. and Hampson, E. L.: A study of strain patterns in jacket crowns on anterior teeth resulting from different tooth preparation, Brit. dent. J., $113: 337-345$, 1962.

52) Rumetsch, W., Schreiber, S. und Motsch, A. : Zur Statik der Jacketkrone: Spantungsoptische Modellversuche, Schweiz. Mschr. Zahnheilk., 75 : 953-975, 1965.

53) Craig, R. G., El-Ebrashi, M. K. and Peyton, F.A.: Experimental stress analysis of dental - restorations, Part II. Two-dimensional photoelastic stress analysis of crowns, J. pros. Dent., $17: 292-302,1967$.

54) Jourdant, R., Jung, T. und Primus, I. F. : Spannungsoptische Untersuchungen an Brückenmodellen, Dtsch. zahnärztl. Z., 23 : 14821487, 1968.

55) Craig, R. G., El-Ebrashi, M. K., LePeak, P. J. and Peyton, F. A.: Experimental stress analysis of dental restorations, Part I. Twodimensional photoelastic stress analysis of inlays, J. pros. Dent., $17: 277-291,1967$.

56) Hanskins, R. C., Haack, D. C. and Ireland, R. L. : A study of stress pattern variations in class II cavity restorations as a result of different cavity designs, J. dent. Res., 33 : 757-766, 1954.

57) Guard, W. F., Haack, D. C. and Ireland, R. L.: Photoelastic stress analysis of buccolingual sections of Class II cavity restorations, J. Amer. dent. Ass., 57 : 631-635, 1959.

58) Mahler, D. B.: An analysis of stresses in a dental amalgam rtesoration, J. dent. Res., $37: 516-526,1958$.

59）村松篤良，塩川延洋，中原一郎：全部朱義菌の 応力分布について, 歯材研報, 1(2):33-41, 1954.

60) Matthews, E. and Wain, E. A.: Stresses in denture bases, Brit. dent. J., 100):167-171, 
1956.

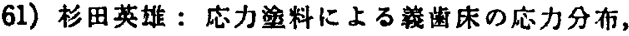
药科理工誌，8：126-137，1967。

62）宝田勇：応力無料のクラスプに対する応用，齿 科学報，63:629-633，1963.

63) Craig, R. G. and Peyton, F. A. : Measurement of stresses in fixed-bridge restorations using a brittle coating technique, J. dent. Res., 44 : 756-762, 1965.

64) 足立学：抵抗線至計による齿牙応力分布の三次 元的砳究，米子医誌，15:300-318，1964.

65) Kakudo, i.Y., Amano, N. and Izumi, K. : Strain on the hard tissue of human teeth biting during and mastication, J. Osaka, dent. Univ., 1 : 167-180, 1967.

66）覚道幸男，天野仁一朗，和泉功一：咬合時およ

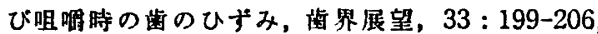
1969.

67) Kydd, W. L., Dutton, D. A. and Smith, D. W. : Lateral forces exerted on abutment teeth by partial dentures, J. Amer. dent. Ass., 68 : 859-863, 1964.

68) Henderson, D. and Seward, T. E. : Design and force distribution with removable partial dentures: A progress report, J. pros. Dent., $17: 350-364,1967$.

69) Shohet, H.: Relative magnitudes of stress on abutment teeth with different retainers, J. pros. Dent., 21 : 267-282, 1969.

70) Regli, C. P. and Kydd, W. L. : A preliminary study of the lateral deformation of metal base dentures in relation to plastic base dentures, J. pros. Dent., 3 : 326-330, 1953.

71) Regli, C. P. and Gaskill, H. L. : Denture base deformation during function, J. pros. Dent., 4 : 548-554, 1954.

72) Frechette, A. R. : Masticatory forces associated with the use of various types of artificial teeth, J. pros. Dent., 5 : 252-267, 1955.

73) Frechette, A. R. : Comparison of balanced and nonbalanced occlusion of artificial dentures based upon distribution of masticatory force, J. pros. Dent., 5 : 801-810, 1955.

74) Kydd, W. L. : Complete denture base deformation with varied occlusal tooth form, J. pros. Dent., 6 : 714-718, 1956.

75) Kydd, W. L. : The comminuting efficiency of varied occlusal tooth form and the associated deformation of the complete denture base, J. Amer. dent. Ass., 61 : 465-471, 1960.

76) Lambrecht, J. R. and Kydd, W. L. : A functional stress analysis of the maxillary complete denture base, J. pros. Dent., 12 : 865-872, 1962.

77) Swoope, C. C. and Kydd, W. L. : The ef- fect of cusp form and occlusal surface area on denture base deformation, J. pros. Dent., $16: 34-43,1966$.

78）関根弘，田岛第治，㧕川浩ほか：莪画の力学的 研究(第 7 報)，クラスプの力学的考察 (そのI), 補緅誌, $7: 83-88,1963$.

79）関根弘，田島篤治，柳川浩ほか：莪谜の力学的 㼋究(第 8 報)，クラスプの力学的焱察 (この2), 被悢誌， $7: 169-175 ， 1963$.

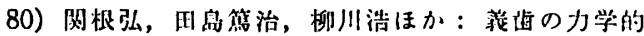
䂨究（第 1 報），口蓋掼の静力学的考察（その1）, 缁科学報, $61: 402-408,1961$.

81）関根弘, 田島第治, 柳川浩ほか：羕均の力学的 研究(第 2 報)，口蓝杆の静力学的考察(三の2), 齿科学報, $62: 234-237,1962$.

82）関根弘，田皇篤治，柳川浩ほか：義齿の力学的 矿究(第 3 報)， 口盐朴の静力学的考察 (その 3 ), 齿科学都, $62: 316-320,1962$.

83）関根弘，四泉第治，柳川浩ほか：義齿の力学的 破究(第 4 報)，口盐杆の种力学的考察，補䋖誌， $6: 57-65,1962$.

84）関根弘, 田息第治, 柳川浩ほか：義悔の力学的 政究(第 5 報), 舌侧们の们力学的考察, 補悢誌, $6: 121-127,1962$.

85) Bates, J. F.: Studies related to the fracture of partial dentures, the functional strain in cobalt-chromium dentures-a prelminary report, Brit. dent. J., $120: 79-83,1966$.

86) 石井恒：ジャケット・クラウンの変形および破 折の機满に関する実雅的研究，修科学報，68： 1571-1604, 1968.

87) Craig, R. G. and Peyton, F. A. : Measurement of strains in fixed bridges with electronic strain gauges: J. dent. Res., 46 : 615619, 1967.

88) Anderson, D. J.: A method of recording masticatory loads, J. dent. Res., 32 : 785-789, 1953.

89）宮内靠, 久保田英陫, 田中誠禾：最近の補能 臨床の統計的観察，蒋科学報，56:322-328， 1956.

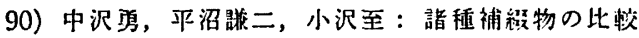
綉計的锶察 (4)，口病誌，26:360-365，1959.

91）角田篤美, 間息道夫, 小会正彦ほか：最近 2 年

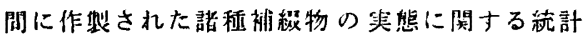
的観察, 補緅䓽, $7: 243-248,1963$.

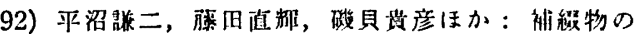

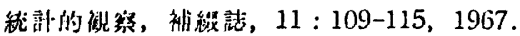

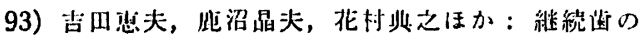

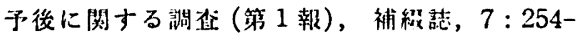
$260,1963$.

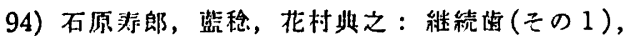
その開題点, ことに保持力について, 幽界展望, 19 : 54-64, 1962.

95) Ackermann, H. : Grundsätzliche Überlegun- 
gen in bezug auf die mechanischen Belange der Stabilität der Stiftzähne, Schweiz. Mschr. Zahnheilk., $63: 799-805,1953$.

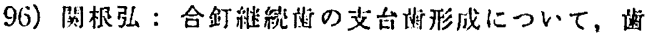
界展望，23:29-38，1964.

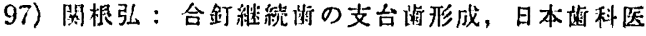
阶会誌, $17: 817-824,1965$.

98) Jankelson, B., Hoffman, G. M. and Hendron. J. A. : The physiology of the stomatognathic system, J. Amer. dent. Ass., 46 : 375-386, 1953.

99）岸本正，木下善之介，宮地和头：前料の傾斜角 度に關する研究，媌科医学，15：190-191，1952。

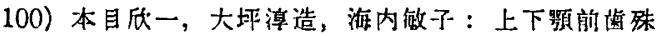
に中切齿の粙傾斜に就いて, 日本齿科医師会誌, $6: 104-105,1953$.

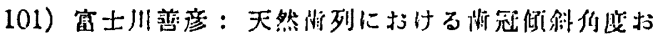
よび捻桠角度の研究，口将贴，25:475-494， 1958.

102) Dempster, W. T., Adams, W. J, and Duddles, R. A.: Arrangement in the jaws of the roots of the teeth, J. Amer. dent. Ass.,
$67: 779-797,1963$.

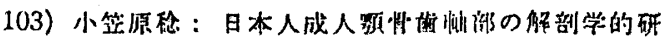

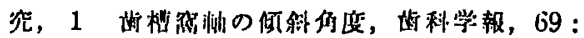
639-664, 1969.

104) Parfitt, G. J.: The dynamics of a tooth in function, J. Periodont., 32 : 102-107, 1961.

105）谷口忠: 棑造力学, 東京, 1968, 䈀菲垩, 143151 頁.

106）奥田克己：最新材料力学, 東宗, 1967, 日刊工 类新閔社, 35-49頁.

107) Koller, K. C. : Zahnersatz durch Kronen, Brücken und partielle Prothesen, Wien, 1954 Wilhelm Maudrich, S. 332-333.

108）花村舆之：継続齿合猃に関する研究，第 2 報,

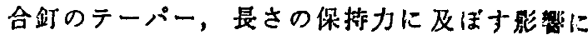
ついて，补悢誌，8:162-172，1964。

109) Colley, I. T., Hampson, E. L. and Lehman, M. L. : Retention of post crowns, An assessment of the relative efficiency of posts of different shapes and sizes, Brit. dent. J., 124 : 63-69, 1968. 